\title{
The Impact of Vascular Disease Treatment on Platelet-Derived Microvesicles
}

\author{
Justyna Rosińska $^{1}$ - Maria Lukasik ${ }^{1}$ - Wojciech Kozubski ${ }^{1}$
}

Published online: 22 November 2017

(C) The Author(s) 2017. This article is an open access publication

\begin{abstract}
Platelet-derived microvesicles (pMVs) are small, heterogeneous vesicles released from platelet membranes as a result of activation. These microvesicles possess a wide range of properties, including prothrombotic, proatherogenic, proinflammatory, immunomodulatory, and even anticoagulant activity. The elevated release of these microvesicles has been observed in various metabolic, inflammatory, thrombotic, and vascular diseases, including ischemic heart disease, stroke, hypertension, diabetes, and connective tissue disease. Modulation of both pMV generation and the expression of their surface molecules may have beneficial clinical implications and could become a novel therapeutic target. However, mechanisms by which pharmacological agents can modify pMV formation are elusive. The purpose of this review is to discuss the effects of drugs routinely used in primary and secondary prevention of vascular disease on the release of pMV and expression of their surface procoagulant and proinflammatory molecules.
\end{abstract}

Keywords Platelet-derived microvesicles (pMV) .

Platelet-derived microparticles · Antiplatelet therapy · Statins · Cerebrovascular disease $\cdot$ Cardiovascular disease

Justyna Rosińska

justynarosinska@interia.pl

1 Department of Neurology, Poznan University of Medical Sciences, ul. Przybyszewskiego 49, 60-355 Poznan, Poland

\section{Introduction}

Platelet-derived microvesicles (pMV) are small (0.1$1.0 \mu \mathrm{m}$ in diameter), heterogeneous vesicles released from platelet membranes as a result of activation following cytoskeletal changes and externalization of the negatively charged inner layer phospholipids. Microvesicles (MVs) of platelet origin, first described in 1967 by Wolf et al. as "platelet dust" [1], being the most abundant and accounting for approximately $70-90 \%$ of all circulating MV $[2,3]$, are currently the best recognized. Although the role of pMV has been overlooked and underestimated for a long time, and they have even been treated as debris, pMVs have recently attracted substantial attention. Circulating pMVs have been widely reported in plasma from healthy individuals $[3,4]$. However, elevated concentrations have been observed in various conditions associated with platelet activation such as ischemic stroke [5-8], coronary artery disease (CAD) [9-11], hypertension [12], diabetes [13], obesity [14, 15], cancer, and metastases [16, 17], suggesting a potential correlation between the quantity of MV and the clinical severity of the disease. Therefore, modulation of pMV generation as well as the exposure of their surface markers may have beneficial clinical implications and become novel therapeutic targets in the treatment of various pathological conditions (Table 1). The number of studies on the impact of drugs on pMV is limited, and their results are equivocal. The research is related mainly to the effect of therapeutic agents used in the prevention of cardiovascular disease (CVD), such as antiplatelet, antihypertensive, and hypolipidemic agents. Most reports are from clinical studies, and little information is available on the mechanisms of action of drugs on pMV release (Fig. 1). Understanding these mechanisms has fundamental clinical and therapeutic implications, especially in vascular diseases. 
Table 1 Potential mechanism of pMV concentration decrease

References Possible mechanism of $\downarrow$ pMV concentration

\begin{tabular}{|c|c|c|}
\hline ASA & {$[9,18]$} & COX-1 inhibition \\
\hline ADP receptor inhibitors & {$[18-21]$} & $\mathrm{P} 2 \mathrm{Y}_{12}$ receptor inhibition, increase intraplatelet concentration of cAMP \\
\hline PDE inhibitors & {$[22-24]$} & PDE3/PDE5 inhibition, increase cAMP concentration \\
\hline GP IIb/IIIa antagonists & [25-28] & GP IIb/IIIa inhibition \\
\hline Heparin & [29] & Mediation of an attractive interaction between phospholipid membranes \\
\hline Statins & {$[30-32]$} & Rho-kinase pathway, activation of PPARs, reduction of NF- $\mathrm{KB}$ activity \\
\hline Fibrates & {$[33,34]$} & $\begin{array}{l}\text { Activation of PPAR- } \alpha \text {, increase cAMP and cGMP concentration, COX-1 inhibition, inhibition of } \mathrm{Ca}^{2+} \text { con- } \\
\text { centration }\end{array}$ \\
\hline PUFAs & [35-37] & Substrates for COX and competition with AA, incorporation into the phospholid cell membrane \\
\hline Hypoglycemic agents & [38-40] & Adiponectin-dependent and NO-dependent pathway \\
\hline $\begin{array}{l}\text { Calcium channel } \\
\text { blockers }\end{array}$ & {$[7,41-44]$} & Calcium influx inhibition and decrease intracellular calcium concentration, PPAR activation \\
\hline Low-calorie diet & {$[14,45]$} & Decrease level of leptin \\
\hline
\end{tabular}

$A A$ arachidonic acid, $A D P$ adenosine diphosphate, $A S A$ acetylsalicylic acid, $c A M P$ cyclic adenosine monophosphate, $C O X$ cyclooxygenase, $N F-\kappa B$ nuclear factor kappa $\mathrm{B}, N O$ nitric oxide, $P D E$ phosphodiesterase, $p M V$ platelet-derived microvesicles, $P P A R$ peroxisome proliferator-activated receptor, PUFAs polyunsaturated fatty acids

\section{Platelet-Derived Microvesicles}

\section{Release of Platelet-Derived Microparticles}

The blebbing of pMV is triggered by platelet activation via high shear stress [46, 47], low temperature [48], hypoxia [49], oxidative stress, endotoxins, and binding of agonists to the membrane receptor [50]. Platelet activation results in signal transduction across the cell membrane, opening of calcium channels, mobilization of calcium ions, and increase in intracellular calcium concentration [51]. It is the principal step in MV formation, leading to activation of several calcium-dependent enzymes and resulting in alteration in the lipid bilayer, loss of membrane phospholipid asymmetry, and externalization of negatively charged phospholipids, mostly phosphatidylserine (PS). Moreover, microparticle blebbing requires degradation and reorganization of cytoskeletal proteins depending mainly on calpains-cytosolic cysteine proteases - that activate integrins and disintegrate structural proteins, including actin-binding protein, talin, and the heavy chain of myosin. Moreover, gelsolin, an enzyme specific to platelets only, decomposes the capping proteins at the ends of the actin filaments. In contrast, the release of apoptotic microparticles depends mainly on activation of caspase 3 as well as Rhoassociated kinase (ROCK). Their activation also leads to cytoskeletal modifications resulting in membrane blebbing [52]. Moreover, the release of MV from resting platelets is calcium and calpain independent, and it is associated with $\alpha \mathrm{II} \beta 3$ integrin-mediated actin cytoskeleton destabilization [53].

\section{Properties of Platelet-Derived Microvesicles}

Platelet-derived microvesicles participate in reactions as platelets do, since they expose various receptors also present on the platelet surface, including integrin glycoprotein (GP) such as GP IIb/IIIa (CD41/CD61), GP IX (CD42a), and GP Ib $\alpha$ (CD42b) [54], as well as CD40L [55] and Pselectin (CD62P) [4, 55, 56]. Ex vivo studies suggest that receptor composition depends on the physiological agonists used to activate platelet vesiculation [57]. However, some of the circulating vesicles exposing typical platelet receptors such as GP IIb/IIIa and containing full-length filamin $\mathrm{A}$ are in fact derived from megakaryocytes, and only those vesicles exposing platelet activation markers such as P-selectin, lysosome-associated membrane protein-1 (LAMP-1), and immunoreceptor-based activation motif receptors are considered truly derived from activated platelets $[58,59]$. Platelet-derived microvesicles also contain many other factors involved in thrombosis, angiogenesis, and inflammation, including platelet-activating factor (PAF) [60], vascular endothelial growth factor (VEGF) [61], $\beta$-amyloid protein precursor [62], anticoagulant protein $\mathrm{C} / \mathrm{S}$ [63], complement $\mathrm{C} 56 \mathrm{~b}-9$, arachidonic acid (AA) [64], and chemokines [65]. Therefore, they exhibit a wide range of activities that are often opposed, including procoagulant as well as anticoagulant, proinflammatory, proatherogenic, and immunomodulatory. Platelet microvesicles participate in various processes such as intercellular communication, atherosclerosis, tissue regeneration, and tumor metastasis. Microvesicles of platelet origin account for approximately $25 \%$ of the procoagulant activity in blood [63], and their surface exhibits 50- to 


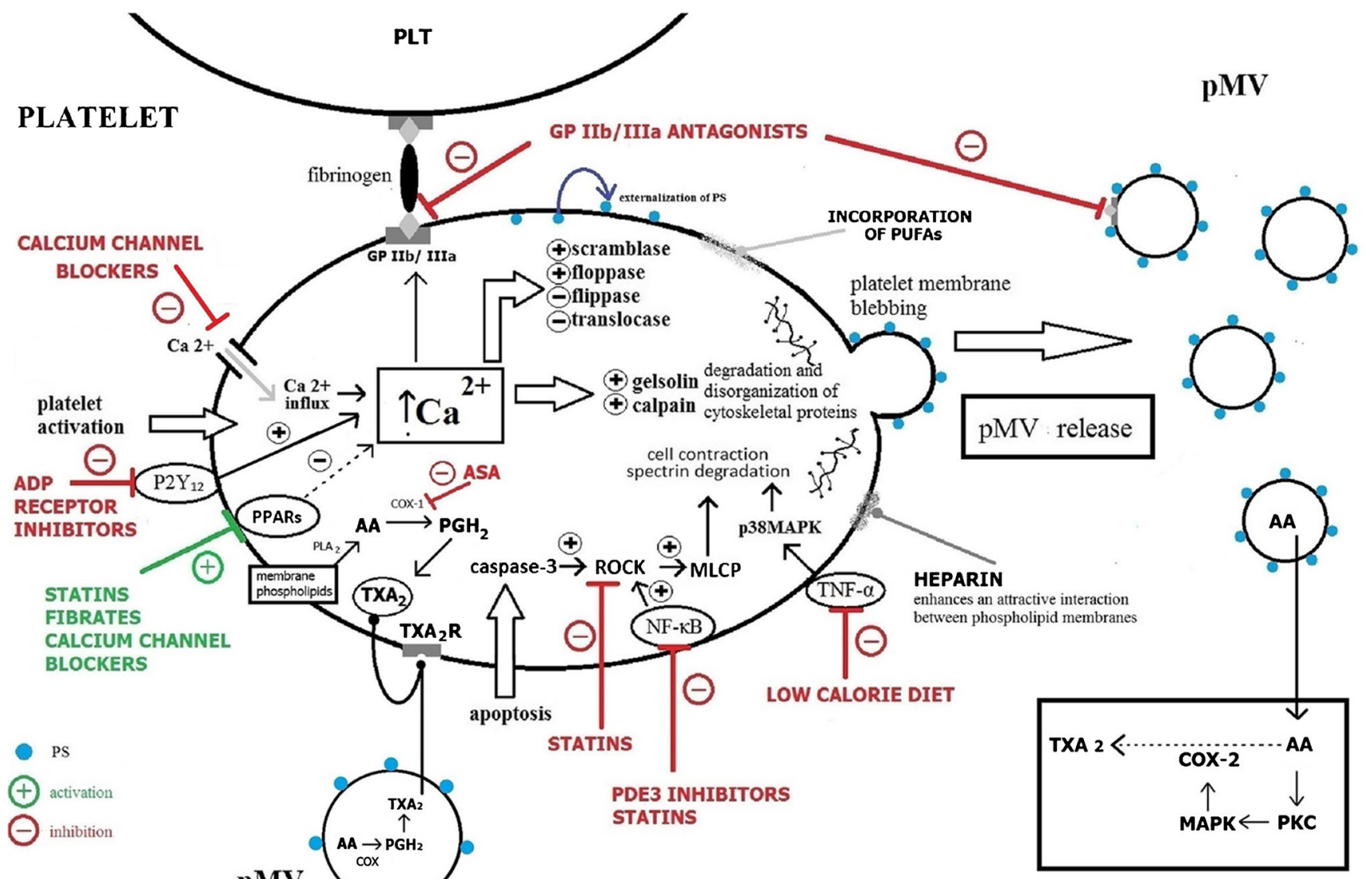

ENDOTHELIAL CELL

Fig. 1 Potential effects of vascular disease treatment on pMV release. Increase in intraplatelet calcium concentration is the principal step in pMV formation. ADP receptor inhibitors increase the intraplatelet concentration of cAMP thereby decreasing platelet vesiculation. GP IIbIIIa antagonists inhibit binding of fibrinogen thereby preventing the second wave of platelet activation. Statins inhibit platelet vesiculation multidirectional - reducing NF- $\mathrm{kB}$ activity and increasing exposure of PPARs and via the ROCK pathway. Fibrates as PPAR agonists increase the levels of both cAMP and cGMP and decrease calcium concentration. Calcium channel blockers inhibit calcium influx and decrease intracellular calcium concentration. Platelet-derived microvesicles transfer AA between platelets and ECs. Microvesicles also metabolize AA to TXA2. AA arachidonic acid, ADP adenosine diphosphate, ASA acetylsalicylic acid, COX cyclooxygenase, GP glycoprotein, MLCP myosin light chain phosphatise, MAPK mitogen-activated protein kinase, NF- $\mathrm{BB}$ nuclear factor kappa B, PDE phosphodiestherase, $\mathrm{PGH} 2$ prostaglandin $\mathrm{H} 2$, PKC protein kinase C, PLA2 phospholipase A2, PLT platelet, p38MAPK mitogen-activated protein kinase p38, pMV platelet-derived microvesicles, PPAR peroxisome proliferator-activated receptor, PS phosphatidylserine, PUFAs polyunsaturated fatty acids, ROCK Rhoassociated protein kinase, TNF- $\alpha$ tumor necrosis factor $\alpha$, TXA2 thromboxane A2, TXA2R thromboxane A2 receptor 100-fold higher procoagulant activity than the surface of activated platelets [66]. This procoagulant effect associated with exposure on their surface of negatively charged phospholipids lasts longer than that caused by activated platelets and is exerted distant from the site of platelet activation [67]. Platelet-derived PS+ microvesicles possess highaffinity binding sites for activated coagulation factors such as factors IXa, Va, Xa, and VIII, providing the background for thrombin formation [68-70]. On the other hand, pMV also exhibits anticoagulant activities by facilitating inactivation of factors Va and VIIIa by activated protein C [63]. The participation of pMV in angiogenesis involves the promotion of endothelial cell (EC) migration, survival, and tube formation as well as stimulation of smooth muscle cell proliferation [16]. Platelet-derived microvesicles also supply AA to ECs and induce endothelial production of cyclooxygenase-2 (COX-2) and vasoconstricting thromboxane A2 (TXA2) [71, 72]. Since pMV contains the proinflammatory chemokine RANTES and exposes $\mathrm{GPIb}-\mathrm{a}$ platelet ligand for leukocyte integrin Mac-1 (CD11b/ $\mathrm{CD} 18, \alpha \mathrm{M} \beta 2$ ) - they are involved in pathogenesis of inflammation and facilitate tethering of monocytes to the activated endothelial cells [64, 72, 73]. Moreover, binding of P-selectin-positive pMV to leukocytes via P-selectinglycoprotein ligand-1 (PGSL-1) results in leukocyte, especially monocyte, activation and rolling [74]. Plateletderived microvesicles deliver CD154 (CD40L) and thus stimulate B cell production of antigen-specific immunoglobulin $\mathrm{G}$ and modulate the adaptive immune response via CD4+ cells [75]. Platelet MVs are also involved in 
tumor growth and metastasis as they promote angiogenesis and transfer GP IIb/IIIa to cancer cells; thus, they facilitate adhesion of cancer cells to fibrinogen and endothelial cells [75]. Platelet microvesicles, as important intercellular carriers of ribonucleic acids such as messenger RNAs (mRNAs) and microRNAs (miRNAs), are able to transfer genetic information and induce changes of gene expression in recipient cells [76].

\section{Methods of pMV Measurement}

Recently, remarkable progress has occurred in the methods of MV detection. Although conventional flow cytometry (FCM) currently remains the most widely used, it is still an imperfect method to identify different subtypes of MV based on their size as well as the presence of specific antigens on their surface using monoclonal antibodies. Some novel techniques, such as nanoparticle tracking analysis, transmission electron microscopy, tuneable resistive pulse sensing, dynamic light scattering, and high-sensitivity or impedance-based FCM, are being introduced to microparticle detection. It should be noted that perfect methods of MV measurement would provide insight not only into cellular origin but also into biochemical properties because both quantitative and qualitative analyses of MV are essential. In the identification of pMV, multiple factors including appropriate blood sample collection (size of the needle used to obtain a blood sample, type of anticoagulant, avoidance of placement of a tourniquet), centrifugation steps during preparation of plasma samples, and conditions of sample storage are important to avoid unwitting platelet activation and heterogeneity of results. The results of MV measurements available in the literature differ significantly because of the variability in pre-analytical conditions, as well as the lack of standardization of the methods [77]. Therefore, wider application of pMV measurement in both the diagnosis and the prognosis of cardiovascular risk, as well as cardiovascular therapy monitoring, is still confined. Hence, it is very important to unify the procedures and protocols, improve the comparison of measurements between the laboratories, and increase sensitivity of flow cytometry. Recently, some initial efforts have been made to standardize the pre-analytical and analytical procedures and improve sensitivity as well as reproducibility of MV detection techniques, such as using size-calibrated fluorescent beads, forward scatter parameter resolution improvement, and reduction of background noise. Platelet-derived microvesicles are the most sensitive to pre-analytical variables; therefore, the International Society on Thrombosis and Hemostasis (ISTH) Vascular Biology Standardization Subcommittee (VB SCC) has organized a first collaborative workshop aimed at standardizing pMV measurement by flow cytometry [78].

\section{The Impact of Pharmacological Modulation on Platelet-Derived Microvesicles}

\section{Antiplatelet Therapy}

\section{Irreversible Cyclooxygenase Inhibitors}

Antiplatelet agents are widely used in both prevention and treatment of vascular disease, but their impact on pMV release is still poorly understood. Acetylsalicylic acid (ASA) is an irreversible inhibitor of the isoenzymes COX-1 and COX-2; thus, it inhibits production of direct prostaglandin (PG) precursors and consequently other prostanoids, prostacyclin (PGI2) and thromboxane A2 (TXA2), from AA. The inhibition of COX-2 is related to the anti-inflammatory effect of ASA, while approximately 170 -fold greater inhibition of COX-1 is responsible for its antithrombotic action [79]. Moreover, ASA initiates formation of anti-inflammatory lipoxins that inhibit proinflammatory processes such as production of tumor necrosis factor alpha (TNF- $\alpha$ ) in T lymphocytes and activation of the transcription nuclear factor-kappa $\mathrm{B}(\mathrm{NF}-\mathrm{kB})$ in monocytes and macrophages. Platelet-derived microvesicles transfer AA-a strong platelet agonist-between platelets, ECs, and monocytes and hence modulate their function $[64,71]$. Microvesicles also metabolize AA to TXA2 and further to its stable form-TXB2 [71]. In human monocytoid cells exposed in vitro to pMV-derived AA, expression of COX-2 and eicosanoid synthesis in a PKC/p42/ p44 MAPK/p38 kinase-dependent manner were observed [80]. Moreover, pMV-derived AA stimulates transcriptional activity of COX-2 as well as c-Jun and Elk-1 proteins, induces chemotaxis of monocytes, and upregulates intracellular cell adhesion molecule-1 (ICAM-1); thus, it enhanced adhesion of monocytes to ECs in vitro [72, 80]. Not only does pMV facilitate transcellular delivery of AA but also endothelially derived $\mathrm{AA}$ is transferred to $\mathrm{pMV}$ and further metabolized to TXA2 [71].

The reports on responsiveness of pMV to treatment with ASA in humans are limited and contradictory. It is worth emphasizing that the available study results are different in terms of the microparticle subtype being evaluated and the methodology that was used. Acetylsalicylic acid reduces pMV production in healthy subjects [18] as well as in patients with hypertensive heart disease and non-significant $(<50 \%$ lumen narrowing) coronary artery disease [9]. Despite this, the vast majority of reports suggest a limited impact of ASA on pMV formation. Acetylsalicylic acid does not significantly affect the release of pMV in either the acute or the chronic phase of ischemic stroke, in patients with multi-infarct dementia, in patients with non-valvular atrial fibrillation $(\mathrm{AF})$ without any previously antithrombotic therapy, or in those in whom treatment was changed from ASA to warfarin [6-8, 81]. No substantial difference in the percentage of pMV was 
found in patients with type 1 or type 2 diabetes before and after use with a low dose of ASA [82, 83], or between diabetic patients treated with aspirin and those who were not undergoing this therapy [13]. Likewise, treatment with ASA also did not modify pMV concentration in patients after an acute coronary syndrome (ACS) [41] in stable CAD patients [84] or those who had undergone coronary angioplasty [85]. Acetylsalic acid therapy had no effect on pMV exposure of tissue factor (TF), P-selectin, or GPIIIa in patients with peripheral arterial occlusive disease (PAOD) [86] and did not affect either the release or the exposure of TF or PS on microvesicles in healthy subjects [87]. These contradictory reports may be the result of different duration of the treatment, dose of ASA, relatively small study groups, and different methodologies used for MV identification and quantification. The lack of effect of ASA on pMV release may also be associated with its insufficient drug serum level, especially since compliance in taking ASA was objectively assessed only in two of the above-cited studies [82, 86]. Moreover, a low dose of ASA might not be sufficient and strong enough to inhibit microvesiculation [87]. In addition, pMV concentrations in healthy subjects are lower than in those suffering from cardiovascular disease; therefore, the effect of antiplatelet agents in this group on MV release may not be as pronounced as in populations with cardiovascular diseases. Further studies are required to assess whether an increased dose of ASA or combination of antiplatelet therapy can reduce pMV formation. It is also necessary to explore the possible role of pMV as a biomarker in monitoring individual response to antiplatelet therapy and to explore the relationship between "ASA resistance" and pMV release.

\section{Adenosine Diphosphate Receptor Inhibitors}

P2 $Y_{12}$ ADP receptor is coupled with the $G_{i}$ protein and adenylyl cyclase pathway, contributing to activation of the GP IIb/IIIa receptor for fibrinogen, which plays an important role in platelet vesiculation [49]. P2Y12 receptor antagonists, through increasing the intraplatelet concentration of cyclic adenosine monophosphate (cAMP), decrease platelet sensitivity to activation and the subsequent platelet vesiculation. The decrease in pMV formation was confirmed in healthy subjects after use of clopidogrel, a thienopyridine class agent irreversibly inhibiting platelet $\mathrm{P} 2 \mathrm{Y}_{12}$ ADP receptor [18], and in patients with ACS treated with clopidogrel and subcutaneous low-molecular-weight heparin [41]. A negative correlation between clopidogrel plasma concentration and pMV release in stable CAD [19], as well as elevated percentage of circulating pMV related to high platelet reactivity on clopidogrel therapy in patients with ACS [88] and in those treated with percutaneous coronary intervention (PCI) [20], confirms that pMVs are potential markers of the antiplatelet effect of clopidogrel.
The active metabolite of prasugrel, a newer thienopyridine P2 $\mathrm{Y}_{12}$ receptor antagonist, as well as the first intravenous antagonist cangrelor, have also been shown to inhibit pMV release in vitro [89-91]. According to our best knowledge, to date, there has been no more research showing the influence of other ADP-P2Y 12 receptor inhibitors, such as ticagrelor or elinogrel, on platelet-derived microvesicles.

\section{Phosphodiesterase Inhibitors}

Cilostazol is a selective reversible inhibitor of phosphodiesterase type 3 (PDE3) that increases the concentration of cAMP in platelets by inhibiting adenosine uptake. It results in inhibition of platelet aggregation related to the cAMP-dependent increase in the active form of protein kinase $\mathrm{A}$ (PKA) in platelets. Moreover, increased cAMP concentration leads to an influx of free calcium ions back into platelet granules, which may have an important role in reducing pMV release. In addition, cilostazol has been shown to increase nitric oxide (NO) production in interleukin (IL) 1b-stimulated vascular smooth muscle cells, resulting in platelet inhibition [92]. Nonetheless, there are conflicting data on the impact of treatment with cilostazol on pMV formation, probably resulting from the varying methodology for determining platelet-derived microvesicles. The level of pMV determined by an enzymelinked immunosorbent assay (ELISA) did not decrease after antiplatelet therapy with cilostazol in the chronic phase of cerebral infarction [8]; however, studies using flow cytometry for $\mathrm{pMV}$ detection reported reduced formation of $\mathrm{pMV}$ in arteriosclerosis obliterans [93] and diabetes [22, 23]. The concentration of circulating pMV was also decreased after combined antiplatelet therapy with cilostazol and ASA in acute ischemic stroke patients with either small or large artery occlusion [24].

Dipyridamole is another PDE3 inhibitor that inhibits cyclic guanine nucleotide degradation by PDE5 in platelets, thus elevating intracellular cyclic guanosine monophosphate (cGMP) and stimulating the release of endothelial PGI2 as well as nitric oxide. Because dipyridamole elevates adenosine and subsequent intraplatelet cAMP, and cilostazol inhibits cAMP breakdown, dipyridamole potentiates the antiplatelet effect from cilostazol $[93,94]$. Indeed, in patients with arteriosclerosis obliterans, combined therapy with cilostazol and dipyridamole reduced the number of pMV compared to treatment with cilostazol alone [93]. Concomitant initial treatment with cilostazol and prednisolone in a patient with active idiopathic thrombocytopenic purpura (ITP) and coexisting acute ischemic stroke resulted in a decrease of pMV count. However, in ITP, the effect of steroids appear to be crucial for affecting the activation status of platelets and decreased pMV release, since the reduction of the steroid dose triggered a re-increase of circulating pMV [95]. 


\section{GP IIb/IIIa Antagonists}

GP IIb/IIIa is the most abundant platelet membrane receptor (approximately 80,000 copies per platelet) [96] and plays a major role in the regulation of platelet aggregation. GP IIb/ IIIa on resting platelets is maintained in an inactive form and serves as a low-affinity adhesion receptor for fibrinogen; however, during platelet activation, a conformational change at the GP IIb/IIIa receptor site allows binding not only to fibrinogen but also to von Willebrand factor, thrombospondin, fibronectin, and vitronectin [97]. Monoclonal antibodies against the GP IIb/IIIa receptor inhibit release of pMV, and the ability to form pMV is severely impaired in patients with Glanzmann's thrombasthenia [49], an inherited platelet disorder of qualitative or quantitative deficiencies in the GP IIb/IIIa receptor. This all confirms that the GP IIb/IIIa complex plays an important role in platelet blebbing. Moreover, the breakdown of the GP IIb/IIIa complex by calcium chelation abolishes $\mathrm{MV}$ blebbing in response to platelet activation with collagen [49]. Since GP IIb/IIIa is crucial for pMV release, dedicated inhibitors appear to be a promising group of drugs affecting MV formation. This has been proven in several in vitro studies with different GP IIb/IIIa antagonists [25, 49, 98, 99]. The release of pMV was also completely abolished by abciximab in healthy donors [26]. There was also a significant decrease of circulating PS+ procoagulant pMV in patients with ST elevation myocardial infarction (STEMI) treated with abciximab after primary PCI compared to patients who did not receive this drug. However, this effect on pMV was not found for another GP IIb/IIIa antagonist, eptifibatide, presumably due to its shorter halflife and reduced affinity for the receptor [25, 27]. Despite this, in patients with NSTEMI, eptifibatide in combined therapy with ASA, enoxaparin, and clopidogrel resulted in a significant fall in the formation of pMV [28]. The lower percentage of pMV observed in GP IIb/IIIa inhibitor-treated patients points to platelet shedding as a possible target of this drug in patients who also received a standard dual antiplatelet therapy with ASA and clopidogrel. Analyzing the effectiveness of PCI on pMV formation is related to difficulties in separating the effect of the invasive procedure from the impact of drugs usually administered during intervention. However, in patients undergoing elective PCI, abciximab reduced periprocedural increase in PMV concentrations, which was not observed among PCI patients not receiving this treatment [100]. Moreover, after bare metal stent (BMS) implantation, the pMV concentration significantly increased compared to diagnostic catheterization alone [101]. Moreover, months after the implantation of coronary stents, the pMV count was significantly higher in the drug-eluting stent (DES) group compared to the BMS group [102].
Other Antiplatelet Agents

A synthetic analog of PGI2-epoprostenol-is a vasodilator and platelet aggregation inhibitor clinically used for the treatment of pulmonary arterial hypertension. Platelet aggregation is inhibited through c-AMP-dependent protein kinase and phosphorylation of vasodilator-stimulated phosphoprotein (VASP). A study conducted in vitro revealed that epoprostenol almost completely inhibits pMV formation [103].

There is no study addressing the effects of new classes of antiplatelet agents, such as vorapaxar (a thrombin protease-activated receptor-1 (PAR-1) antagonist) or the thromboxane receptor antagonist terutroban, on pMV formation. However, pMVs are a promising new target for these drugs and deserve further research.

\section{Anticoagulants}

\section{Heparins}

In the course of heparin-induced thrombocytopenia (HIT), binding of heparin-dependent immunoglobulin $\mathrm{G}$ to platelet Fc $\gamma$ RIIa receptor (CD32a) led to platelet activation and the generation of procoagulant pMV associated with thrombotic complications [104]. Therefore, when HIT is suspected, heparin should be discontinued and an alternative anticoagulant agent should be considered to prevent thromboembolic events. Nevertheless, long-term anticoagulant therapy with the low-molecular-weight heparin (LMWH) tinzaparin led to a decrease in the procoagulant activity of circulating MV in patients with deep venous thrombosis (DVT). This effect was not observed in patients with DVT initially treated with vitamin $\mathrm{K}$ antagonists such as acenocoumarol, and even an increase of procoagulant activity of MV was observed in this group of patients [105].

More attention has been paid recently to the beneficial role of heparin in cancer and metastases [106]. One of its anticoagulant as well as antineoplastic mechanisms is the mediation of the release of extracellular MV, including that of platelet origin. Heparins suppress microvesiculation by mediating an attractive interaction between phospholipid membranes and thereby also act as antitumor agents [29]. Therapeutic doses of nadroparin added to the blood samples of healthy donors and patients with gastrointestinal cancer and rheumatoid arthritis suppressed microvesiculation [29]. Furthermore, heparin has also been shown to block transfer of MV and hence derived contents such as proteins, RNA, and miRNA into recipient cells. Such mechanisms of heparins' action may be considered in the context of therapeutic strategies for the treatment of vascular diseases in which MVs play an important role. 


\section{Vitamin K Antagonist}

In patients with non-valvular AF without any previous antithrombotic therapy, initiation of oral anticoagulation with warfarin (the target range for the international normalized ratio was 2 to 3 ) did not significantly affect the release of plateletderived microvesicles [81]. Moreover, there were no significant differences in pMV concentration among AF patients who were receiving ASA and warfarin. In the AF patients in whom antithrombotic treatment was changed from ASA to warfarin, there was also no significant effect on pMV release [81]. As mentioned above, decrease in the procoagulant activity of circulating MV was also not observed in patients with DVT treated with the vitamin $\mathrm{K}$ antagonist acenocoumarol, and even an increase of this activity was observed [105].

\section{Others}

Bivalirudin, a specific and reversible direct thrombin inhibitor (DTI), administered periprocedurally during PCI in a patient with CAD, compared to unfractionated heparin (UFH), reduced the thrombogenicity of pMV measured by TF activity of pMV stimulated with TRAP or ADP [107].

Platelet-derived microvesicles have been demonstrated to express factor Xa activity at their surface, and hence, they possess significant procoagulant activity [108]. The inhibiting effect of factor Xa inhibitors on the prothrombinase activity of pMV both in vitro and in vivo was observed in an animal model [109]. However, direct inhibitors of factor Xa, such as apixaban and rivaroxaban, did not affect platelet activation after stimulation with different agonists [110]; thus, their impact on pMV blebbing is probably negligible. Currently, no data are available on the effect of novel anticoagulants, such as direct inhibitors of factor $\mathrm{Xa}$ (fondaparinux, rivaroxaban, apixaban, or edoxaban) and the thrombin inhibitor dabigatran, on pMV formation.

\section{Hypolipemic Therapy}

\section{HMG-CoA Reductase Inhibitors (Statins)}

In addition to the well-recognized lipid-lowering effect, the pleiotropic effect of 3-hydroxy-3-methylglutaryl-coenzyme A (HMG-CoA) reductase inhibitors (statins) includes endothelial function improvement, reduction of thrombin generation, atherosclerotic plaque stabilization, decrease in expression, and activity of many inflammatory agents and metalloproteinases. Increasing evidence indicates that statins limit platelet activation and aggregation. Modifying $\mathrm{G}$ protein functions and the Rho kinase pathway, both involved in cytoskeleton reorganization, statins affect pMV shedding, decreasing the number of MV in a lipid-independent manner [111, 112]. Moreover, statins significantly reduce the surface exposure of proinflammatory CD40L on platelets [113] as well as on pMV [114].

HMG-CoA reductase inhibitors contribute to reduced $\mathrm{NF}-\mathrm{KB}$ activity and increased exposure of peroxisome proliferator-activated receptors (PPARs); thus, they affect the release of many proinflammatory cytokines and chemokines [115], thereby limiting platelet activation.

Hypercholesterolemic patients treated with simvastatin, atorvastatin, or rosuvastatin have lower pMV concentrations compared to untreated patients with the same plasma lipid levels [111]. The percentage of pMV was also decreased after therapy with simvastatin in hyperlipidemic patients after ischemic stroke [30]. Withdrawal of rosuvastatin in patients with coronary heart disease (CHD) caused an increase in the formation of circulating $\mathrm{pMV}$ despite continuation of treatment with clopidogrel [31]. Combined therapy with simvastatin and losartan reduced pMV concentrations in patients with hypertension and type 2 diabetes as well [114]. Pitavastatin alone did not decrease pMV in hyperlipidemic, diabetic patients; however, the addition of eicosapentaenoic acid (EPA) significantly lowered the proportion of pMV, and the reduction was even greater than that observed with EPA alone [35]. Thus, pitavastatin enhances the antiplatelet effect of EPA in an adiponectin-dependent pathway. In patients with PAOD as well as diabetes with dyslipidemia, combined treatment with atorvastatin and ASA significantly reduced TF, Pselectin, and GPIIIa exposure on pMV, while the exposure of PS was not influenced by atorvastatin [86, 116]. Lipidlowering treatment with simvastatin reduced the total count of procoagulant pMV as well as the exposure of P-selectin, CD40L, and TF on pMV in diabetic patients with chronic kidney disease. However, in diabetic patients without kidney disease, a reduction of pMV percentage was not achieved until combined therapy with simvastatin and ezetimibe was applied [32]. This suggests that in patients with diabetes and concomitant kidney disease, increased platelet activation is observed and pMVs are involved in the hypercoagulable state in chronic kidney disease. Treatment with pravastatin significantly reduced the GPIIIa receptor for fibrinogen on pMV in type 2 diabetes patients with no effect on the number of pMV or the exposure of TF antigen [117].

\section{Fibrates}

Bezafibrate is an agonist of PPAR-alpha, which are also present in human platelets and are involved in many biological functions such as inflammation, atherosclerotic plaque formation, and lipid metabolism. Activation of PPARs inhibits platelet function via inhibition of PKC $\alpha$ and increases the levels of both cAMP and cGMP [118, 119]. The antiplatelet effect of PPAR agonists is also associated with direct inhibition of COX-1 [120] as well as indirect inhibition of intracellular $\mathrm{Ca}^{2+}$ mobilization, TXA2 production, exposure of $\mathrm{P}$ - 
selectin, and pMV release. Decreased formation of pMV is presumably caused by reduced calcium concentration, inhibition of PKC, and activation of PKA via increased concentration of cAMP [33].

The proportion of pMV was significantly decreased after treatment with bezafibrate in patients with connective tissue diseases and secondary hyperlipidemia caused by long-term steroid administration, as well as in patients with diabetes without obstructive CAD burdened with elevated levels of remnant-like particle cholesterol (RLP-C) [33, 34]. RLP-C in vitro increases intracellular oxidative stress, reduces $\mathrm{NO}$, and affects endothelial-dependent vasorelaxation, thus inducing platelet activation. Therefore, RLP-C may be a target, since a decrease of its elevated level also results in the reduction of pMV formation and lower incidence of cardiovascular events in patients with diabetes [34].

\section{Inhibitors of Cholesterol Intestinal Absorption}

Ezetimibe selectively inhibits the intestinal absorption of cholesterol without inhibition of cholesterol synthesis in the liver or increase of bile acid excretion [121]. Treatment with ezetimibe showed no effect on pMV either in subjects with stable CHD or in those with CHD risk factors receiving double therapy with simvastatin and ezetimibe [84, 122]. Moreover, it was demonstrated that in diabetic patients with chronic kidney disease, combined therapy with ezetimibe and simvastatin had no further effect on pMV formation compared to simvastatin therapy alone [32].

Although preliminary reports suggested that shedding of pMV is the result of changes in cholesterol content within platelet membranes [123], the lack of association between cholesterol concentration and glycoprotein exposure on pMV refutes that mechanism [86].

\section{Other Hypolipidemic Treatment}

In patients with familial hypercholesterolemia, the procedure of lipoprotein apheresis not only removed LDL-cholesterol but also reduced the concentration of $\mathrm{MV}$, although the percentage of annexin V-positive MV, including those of platelet origin, did not change [124]. There is no study addressing the effects of other hypolipidemic agents such as niacin and bile acid sequestrants or new promising agents such as proprotein convertase subtilisin/kexin type 9 (PCSK9) inhibitors or cholesterylester transfer protein (CETP) inhibitors on pMV, and further studies are needed.

\section{Hypoglycemic Therapy}

Platelet-derived microvesicles are elevated in diabetes and play an important role in the development of atherosclerotic vascular complications in this condition [125]. Postprandial hyperglycemia resulting in decrease in NO production is thought to be a significant factor of platelet activation in diabetes [38]. The reports on the effects of hypoglycemic agents on the release and procoagulant activity of pMV are limited to $\alpha$-glucosidase inhibitors, teneligliptin and mitiglinide. Alphaglucosidase inhibitors mainly reduce postprandial hyperglycemia and hyperinsulinemia via inhibition of the absorption of carbohydrates from the intestine. Gliptins such as teneligliptin are dipeptidyl peptidase-4 (DPP-4) inhibitors that increase concentrations of active incretin hormones such as gutderived glucagon-like peptide-1 (GLP-1) and glucosedependent insulinotropic peptide. It leads to the stimulation of insulin release and inhibition of glucagon release and therefore decreases blood glucose. Presumably, the antiplatelet effects of these drugs, including the reduction of pMV release, are adiponectin and NO dependent [39]. Low NO concentration related to hypoadiponectinemia and postprandial hyperglycemia results in platelet activation [126]. Therefore, increased concentrations of adiponectin caused by mitiglinide exert an antiplatelet effect by promoting NO production, and improvement of hypoadiponectinemia may result from decreased pMV formation [127]. Moreover, therapy with both $\alpha$-glucosidase inhibitors and gliptins enhances active GLP-1 secretion, which subsequently promotes adiponectin secretion [40, 128].

Hypoglycemic therapy with the $\alpha$-glucosidase inhibitors acarbose [40] and miglitol [38] significantly decreased the percentage of $\mathrm{pMV}$, which was considerably higher in diabetic patients with a previous history of thrombotic complications than in the non-thrombotic group. Administration of mitiglinide in monotherapy as well as combined therapy to diabetic patients significantly reduced plasma concentrations of pMV [127]. Teneligliptin therapy also significantly reduced the pMV number in diabetic subjects, with a more significant reduction in hemodialyzed patients than in those not dialyzed [39]. However, these subjects received teneligliptin monotherapy or teneligliptin in combination with other antidiabetic drugs, and therefore, evaluation of the therapeutic effects is difficult.

At the moment, there are no more studies addressing the effects of other hypoglycemic agents on pMV formation; however, the group of antidiabetic agents, including PPARgamma agonists such as pioglitazone and rosiglitazone, are promising drugs affecting MV $[129,130]$ and potentially also pMV release because of attenuating platelet activation.

\section{Antihypertensive Therapy}

Increased formation of pMV in hypertension is associated with activation of platelets as a result of elevated shear force. The formation of pMV positively correlates with both systolic and diastolic blood pressure [12]. The main stage of MV release is an increase in cytoplasmic calcium ions associated 
with the opening of plasma membrane calcium channels. Therefore, the calcium channel blockers that inhibit calcium influx and decrease intracellular calcium concentration are promising agents hampering the process of microvesiculation. Moreover, dihydropyridine calcium channel blockers enhance NO activity and increase adiponectin concentration, which regulate platelet activation and hence microvesiculation [131]. Beneficial effects of nifedipine, a dihydropyridine calcium channel blocker and PPAR agonist, on reducing pMV formation were observed in patients with transient ischemic attacks [7] as well as in hypertensive patients with type 2 diabetes $[42,43]$. A decrease in pMV number was also observed in hypertensive patients with type 2 diabetes after treatment with efonidipine, another dihydropyridine calcium channel blocker [44], and in patients with ACS treated with different calcium channel antagonists compared to those not receiving such treatment [41, 85].

The angiotensin II receptor antagonists (sartans) are able to selectively inhibit the platelet angiotensin II type 1 receptor, with the result of lower responsiveness of platelets to increased intracellular $\mathrm{Ca}^{2+}$ levels, and consequently inhibit MV blebbing. In monotherapy of hypertensive patients, eprosartan normalized the elevated percentage of pMV [132]. In hypertensive patients with diabetes, the percentage of pMV was also decreased during monotherapy with another angiotensin receptor blocker, losartan. Furthermore, the decrease of pMV number was greater in hypertensive and hyperlipidemic patients administered combined therapy with losartan and simvastatin than in those without type 2 diabetes [114], preventing the development of cardiovascular complications via a mechanism other than reduction of the blood pressure or lipid levels.

Spironolactone is a potassium-sparing diuretic that, among other effects, decreases intraplatelet $\mathrm{Na}^{+}$and $\mathrm{Ca}^{2+}$ concentration by reducing activity of the $\mathrm{Na}^{+}$pump [123]. In an experimental rat model of aldosterone-mediated hypertension, the diminished pMV formation observed after spironolactone treatment presumably is associated with a lower increase in intracellular $\mathrm{Ca}^{2+}$ in platelets [133].

\section{Non-Pharmacological Interventions}

Dietary and life style modification are the first-line prevention and therapy for vascular diseases.

It has been proven that a diet enriched in omega- 3 polyunsaturated long-chain fatty acids (PUFAs) is associated with reduced incidence of thrombotic events. Beneficial effects of PUFAs such as EPA or docosahexaenoic acid (DHA) in vascular diseases include improvement of endothelial function, inhibition of platelet aggregation, and decrease in blood pressure and plasma triglyceride concentration. Omega-3 fatty acids, as substrates for COX, compete with AA, resulting in reduced formation of proaggregatory eicosanoids. Moreover, incorporation of omega-3 PUFAs, especially EPA, into the phospholipid cell membranes leads to membrane remodeling then improves the rheological properties of blood and reduces platelet activation [134]. A single oral dose of EPA-rich oils immediately and significantly reduced the pMV procoagulant activity determined by the annexin $\mathrm{V}$ binding and thrombin generation in healthy individuals, probably by incorporating fatty acids into the platelet membrane. Simultaneously, there were no changes in pMV number, suggesting that the new pMVs generated following EPA supplementation were less procoagulant [134]. Combined long-lasting administration of EPA and DHA also caused normalization of TF-dependent procoagulant activity of pMV in patients after myocardial infarction, with no significant effect on the total number of microvesicles [36]. In contrast, the percentage of pMV decreased significantly in hyperlipidemic, diabetic patients receiving EPA $[35,37]$. In spite of the fact that the omega-3 PUFAs are thought to exhibit presumed protective effects in CVD, there is currently a lack of strong evidence to recommend the routine use of omega-3 PUFAs in the primary and secondary prevention of cardiovascular disease [135].

Excessive adipose tissue is associated with increased formation of pMV [14], and pMV release positively correlates with increased thrombin formation in obese subjects [136]. Adipose tissue induces low-grade inflammation and produces cytokines such as TNF- $\alpha$ and IL- 6 that enhance pMV production [21]. In obese patients, an increased level of leptin promotes ADP-induced platelet aggregation and therefore also ADP-induced pMV generation [137, 138]. Moreover, even in normal-weight acute stroke subjects, increased pMV formation positively correlated with plasma leptin concentrations [139]. Elevated plasma concentrations of oxidative stress markers, such as oxidized low-density lipoprotein (oxLDL), promote the shedding of pMV both in vitro [140] and in vivo [141].

In a rat model, a long-term high-fat diet providing $60 \%$ energy as fat generated a significant increase of total MV with a significantly elevated number of pMV [142]. A similar process was also observed after two consecutive high-fat meals in healthy men [141]. Introduction of a short-term, very-low-calorie diet in obese women resulted not only in the reduction of body weight, lowering of blood pressure, and improvement of metabolic parameters but also a significant reduction in the percentage of procoagulant pMV [45]. Body weight loss by reducing calorie restriction with as well as without aerobic physical exercise also decreases the number of pMV, probably through reduction of the amount of adipose tissue [14].

The oat is considered a low glycemic index plant, which is expected to modulate postprandial hyperglycemia and exert direct anti-inflammatory and antioxidant effects. An oatenriched diet in patients with type 2 diabetes reduced both the concentration and the proportion of TF-positive pMV 
Table 2 The impact of vascular disease treatment on platelet-derived microvesicles

\begin{tabular}{|c|c|c|c|c|c|}
\hline & Population/disease & $\begin{array}{l}\text { Treatment strategy/dose and } \\
\text { duration }\end{array}$ & $\begin{array}{l}\text { Effect on pMV } \\
\text { concentration }\end{array}$ & Reference & $\begin{array}{l}\text { Supplementary } \\
\text { information }\end{array}$ \\
\hline \multirow[t]{13}{*}{$\begin{array}{l}\text { COX } \\
\quad \text { inhibitors: ASA }\end{array}$} & Healthy subjects & $100 \mathrm{mg} /$ day for 3 or 7 days & $\downarrow$ & [18] & $\begin{array}{l}\downarrow \text { ADP-induced pMV forma- } \\
\text { tion }\end{array}$ \\
\hline & Healthy volunteers & $100 \mathrm{mg} /$ day for 7 days & No effect & {$[87]$} & \\
\hline & $\begin{array}{l}\text { Hypertensive heart disease } \\
\text { and non-significant } \\
(<50 \% \text { lumen } \\
\text { narrowing) CAD }\end{array}$ & $\begin{array}{l}\text { Chronic treatment ( } 8 \text { weeks) with a } \\
\text { dose of } 100 \mathrm{mg} / \text { day }\end{array}$ & $\downarrow$ & [9] & \\
\hline & Acute ischemic stroke & No data available & No effect & {$[6]$} & SP \\
\hline & $\begin{array}{l}\text { TIA, ischemic stroke, } \\
\text { multi-infarct dementia }\end{array}$ & No data available & No effect & [7] & $\mathrm{SP}$ \\
\hline & $\begin{array}{l}\text { Chronic phase of ischemic } \\
\text { stroke }\end{array}$ & $100 \mathrm{mg} /$ day for 4 weeks & No effect & {$[8]$} & SP \\
\hline & $\mathrm{AF}$ & $150 \mathrm{mg} /$ day for 4 weeks & No effect & [81] & PP \\
\hline & Diabetes & $100 \mathrm{mg} /$ day for 10 or 15 days & No effect & {$[82,83]$} & $\mathrm{PP}$ \\
\hline & Patients after ACS & $75 \mathrm{mg} /$ day for 6 months & No effect & [41] & $\mathrm{SP}$ \\
\hline & $\begin{array}{l}\text { PAOD and } \\
\text { hypercholesterolemia }\end{array}$ & $320 \mathrm{mg} /$ day for 8 weeks & No effect & {$[86]$} & $\mathrm{PP}$ \\
\hline & Diabetes & No data available & No effect & [13] & \\
\hline & Stable CAD & $100 \mathrm{mg} /$ day for 1 week & No effect & {$[84]$} & \\
\hline & $\begin{array}{l}\text { CAD patients undergoing } \\
\text { coronary angioplasty }\end{array}$ & No data available & No effect & {$[85]$} & \\
\hline \multirow[t]{6}{*}{$\begin{array}{l}\text { ADP receptor } \\
\text { inhibitors }\end{array}$} & Healthy subjects & $75 \mathrm{mg} /$ day clopidogrel for 3 days & $\downarrow$ & [18] & $\begin{array}{l}\downarrow \text { ADP-induced pMV forma- } \\
\text { tion }\end{array}$ \\
\hline & Healthy volunteers & $\begin{array}{l}\text { Administration of a loading dose } \\
\text { (60 mg) of prasugrel }\end{array}$ & $\downarrow$ & {$[86]$} & in vitro study \\
\hline & Stable CAD & $75 \mathrm{mg}$ /day clopidogrel for 3 weeks & $\downarrow$ & [19] & $\begin{array}{l}\text { Negative correlation between } \\
\text { clopidogrel plasma } \\
\text { concentration and pMV } \\
\text { release }\end{array}$ \\
\hline & ACS patients & $\begin{array}{l}\text { Clopidogrel (loading dose of } \\
600 \mathrm{mg} \text { followed by a } \\
\text { maintenance dose of } 75 \mathrm{mg} / \text { day) } \\
\text { for } 30 \text { days }\end{array}$ & $\downarrow$ & [88] & $\begin{array}{l}\text { high-on clopidogrel platelet } \\
\text { reactivity associated with } \\
\text { higher pMV concentration } \\
\text { SP }\end{array}$ \\
\hline & ACS patients & $\begin{array}{l}\text { Clopidogrel and subcutaneous } \\
\text { LMWH (i.e., enoxaparin } 1 \mathrm{mg} \text { per } \\
\text { kg body weight twice daily) }\end{array}$ & $\downarrow$ & [41] & SP \\
\hline & ACS treated with PCI & $\begin{array}{l}\text { Oral loading dose of ASA }(500 \mathrm{mg}) \\
\text { and clopidogrel }(600 \mathrm{mg}), \text { then } \\
\text { DAPT ( } 75 \mathrm{mg} / \text { day ASA and } \\
75 \mathrm{mg} / \text { day clopidogrel }) \text { for } \\
12 \mathrm{months}\end{array}$ & $\downarrow$ & {$[20]$} & $\begin{array}{l}\text { pMV concentration higher in } \\
\text { patients with high platelet } \\
\text { reactivity (assessed by } \\
\text { impedance aggregometry); } \\
\text { SP }\end{array}$ \\
\hline \multirow[t]{6}{*}{ PDE inhibitors } & $\begin{array}{l}\text { Chronic phase of ischemic } \\
\text { stroke }\end{array}$ & $200 \mathrm{mg} /$ day cilostazol for 4 weeks & No effect & {$[8]$} & SP \\
\hline & Arteriosclerosis obliterans & $\begin{array}{l}100 \mathrm{mg} / \text { day cilostazol for } 2 \text { weeks } \\
\text { or combined therapy with } \\
\text { cilostazol }(100 \mathrm{mg} / \text { day }) \text { and } \\
\text { dipyridamole }(150 \mathrm{mg} / \text { day }) \text { for } \\
14 \text { weeks }\end{array}$ & $\downarrow$ & [93] & $\begin{array}{l}\downarrow \text { pMV number (more } \\
\text { significant on combined } \\
\text { therapy) }\end{array}$ \\
\hline & $\begin{array}{l}\text { Non-insulin-dependent } \\
\text { diabetes }\end{array}$ & $150 \mathrm{mg} /$ day cilostazol for 4 weeks & $\downarrow$ & {$[22]$} & \\
\hline & Diabetes with nephropathy & $150 \mathrm{mg}$ cilostazol & $\downarrow$ & {$[23]$} & \\
\hline & Acute ischemic stroke & $\begin{array}{l}\text { combined therapy with cilostazol } \\
(200 \mathrm{mg} / \text { day) and ASA } \\
(100 \mathrm{mg} / \text { day }) \text { for } 4 \text { weeks }\end{array}$ & $\downarrow$ & {$[24]$} & SP \\
\hline & $\begin{array}{l}\text { ITP patient with ischemic } \\
\text { stroke }\end{array}$ & $\begin{array}{l}\text { Combined therapy with } 200 \mathrm{mg} / \text { day } \\
\text { cilostazol and prednisolone } \\
(30 \mathrm{mg} / \text { day }) \text { for } 30 \text { days }\end{array}$ & $\downarrow$ & {$[95]$} & $\begin{array}{l}\text { Elevation of pMV } \\
\text { concentration after decrease } \\
\text { in prednisolone dose }\end{array}$ \\
\hline
\end{tabular}


Table 2 (continued)

\begin{tabular}{|c|c|c|c|c|c|}
\hline & Population/disease & $\begin{array}{l}\text { Treatment strategy/dose and } \\
\text { duration }\end{array}$ & $\begin{array}{l}\text { Effect on pMV } \\
\text { concentration }\end{array}$ & Reference & $\begin{array}{l}\text { Supplementary } \\
\text { information }\end{array}$ \\
\hline & & $\begin{array}{l}\text { Combined therapy with } \\
\text { dexamethasone ( } 40 \mathrm{mg} / \text { day for } \\
4 \text { days), prednisolone } \\
\text { ( } 30 \mathrm{mg} / \text { day), and cyclosporine } \\
\text { ( } 250 \mathrm{mg} / \text { day) for } 1 \mathrm{month}\end{array}$ & $\downarrow$ & & $\begin{array}{l}\text { Revision of } \\
\text { immunosupressive therapy } \\
\text { resulted in normalization of } \\
\text { plasma pMV } \\
\text { SP }\end{array}$ \\
\hline \multirow[t]{6}{*}{$\begin{array}{l}\text { GP IIb/IIIa } \\
\text { inhibitors }\end{array}$} & $\begin{array}{l}\text { Medication-free normal } \\
\text { volunteers }\end{array}$ & $\begin{array}{l}\text { Abciximab }(10 \mu \mathrm{g} / \mathrm{mL} \\
\quad \text { approximately } 0.2 \mu \mathrm{m})\end{array}$ & $\downarrow$ & {$[25]$} & In vitro study \\
\hline & Healthy donors & Abciximab & $\downarrow$ & {$[26]$} & \\
\hline & $\begin{array}{l}\text { Medication-free normal } \\
\text { volunteers }\end{array}$ & $\begin{array}{l}0.5 \mu \mathrm{m} \text { tirofiban or } 0.5 \mu \mathrm{m} \\
\text { eptifibatide }\end{array}$ & No effect & {$[25]$} & $\begin{array}{l}\text { In vitro study } \\
\text { No effect as a result of } \\
\text { eptifibatide shorter half-life } \\
\text { and reduced affinity for the } \\
\text { receptor }\end{array}$ \\
\hline & STEMI after PCI & $\begin{array}{l}\text { Abciximab (one } 250 \mu \mathrm{g} / \mathrm{kg} \text { bolus } \\
\text { followed by } 0.125 \mu \mathrm{g} / \mathrm{kg} / \mathrm{min} \\
\text { continuous infusion up to } 12 \mathrm{~h} \text { ) } \\
\text { plus standard DAPT (ASA + } \\
\text { clopidogrel) }\end{array}$ & $\downarrow$ & {$[27]$} & SP \\
\hline & STEMI after PCI & $\begin{array}{l}\text { Eptifibatide (one } 180 \mu \mathrm{g} / \mathrm{kg} \text { bolus } \\
\text { followed by } 2 \mu \mathrm{g} / \mathrm{kg} / \mathrm{min} \\
\text { continuous infusion up to } 18 \mathrm{~h} \text { ) } \\
\text { plus standard DATP (ASA + } \\
\text { clopidogrel) }\end{array}$ & No effect & {$[27]$} & $\begin{array}{l}\text { No effect as a result of } \\
\text { eptifibatide shorter half life } \\
\text { and reduced affinity for the } \\
\text { receptor } \\
\text { SP }\end{array}$ \\
\hline & NSTEMI & $\begin{array}{l}\text { Eptifibatide ( } 180 \mu \mathrm{g} / \mathrm{kg} \text { IV bolus, } \\
\text { followed by an infusion of } \\
2 \mu \mathrm{g} / \mathrm{kg} \text { per min) given in } \\
\text { addition to ASA ( } 500 \mathrm{mg} \text { bolus } \\
\text { IV followed by } 75 \mathrm{mg} / \mathrm{day} \\
\text { orally), enoxaparin }(1 \mathrm{mg} / \mathrm{kg} \\
\text { twice a day subcutaneously), and } \\
\text { clopidogrel (oral loading dose } \\
300 \mathrm{mg} \text { ) }\end{array}$ & $\downarrow$ & {$[28]$} & SP \\
\hline \multirow[t]{3}{*}{ Anticoagulants } & DVT & $\begin{array}{l}\text { Long-term (for } 3 \text { months) } \\
\text { anticoagulant therapy with a } \\
\text { LMWH-tinzaparin (175 IU/kg } \\
\text { per day) }\end{array}$ & $\downarrow$ & {$[105]$} & $\begin{array}{l}\text { The decrease of procoagulant } \\
\text { activity of MV }\end{array}$ \\
\hline & DVT & $\begin{array}{l}\text { Vitamin } \mathrm{K} \text { antagonist- } \\
\text { acenocoumarol for } 3 \text { months }\end{array}$ & $\uparrow$ & {$[105]$} & $\begin{array}{l}\text { The increase of procoagulant } \\
\text { activity of MV }\end{array}$ \\
\hline & Non-valvular AF & $\begin{array}{l}\text { Oral anticoagulation with vitamin } \mathrm{K} \\
\text { antagonist, warfarin (with the } \\
\text { target range for INR, } 2 \text { to } 3 \text { ) }\end{array}$ & No effect & {$[81]$} & PP \\
\hline \multirow[t]{5}{*}{ Statins } & PAOD & $\begin{array}{l}\text { Combined therapy with atorvastatin } \\
(80 \mathrm{mg} / \text { day) and ASA } \\
(320 \mathrm{mg} / \text { day }) \text { for } 8 \text { weeks }\end{array}$ & $\begin{array}{l}\downarrow \text { Exposition of } \\
\text { TF, P-selectin, } \\
\text { GPIIIa on } \\
\text { pMVs }\end{array}$ & {$[86]$} & \\
\hline & $\begin{array}{l}\text { Hypercholesterolemic } \\
\text { patients }\end{array}$ & $\begin{array}{l}\text { Different statins: simvastatin } \\
\text { (20 mg/day), atorvastatin } \\
(20 \mathrm{mg} / \text { day }) \text {, or rosuvastatin } \\
(10 \mathrm{mg} \text { /day) }\end{array}$ & $\downarrow$ & [111] & $\begin{array}{l}\text { Compare to untreated patients } \\
\text { with the same plasma lipid } \\
\text { level } \\
\text { PP }\end{array}$ \\
\hline & $\begin{array}{l}\text { Hypertensive and } \\
\text { hyperlipidemic patients } \\
\text { with type } 2 \text { diabetes }\end{array}$ & $\begin{array}{l}\text { Combined therapy simvastatin } \\
(10 \mathrm{mg} / \text { day }) \text { and losartan } \\
(50 \mathrm{mg} / \text { day }) \text { for } 24 \text { weeks }\end{array}$ & $\downarrow$ & [114] & \\
\hline & $\begin{array}{l}\text { Hyperlipidemic patients } \\
\text { after ischemic stroke } \\
\text { confirmed by CT }\end{array}$ & Simvastatin $20 \mathrm{mg} /$ day for 6 months & $\downarrow$ & {$[30]$} & SP \\
\hline & $\mathrm{CAD}$ & $\begin{array}{l}\text { Withdrawal of rosuvastatin } \\
\text { (rosuvastatin was given at daily }\end{array}$ & $\downarrow$ & {$[31]$} & $\begin{array}{l}\text { Increase of pMV amount after } \\
\text { rosuvastatin withdrawal }\end{array}$ \\
\hline
\end{tabular}


Table 2 (continued)

\begin{tabular}{|c|c|c|c|c|c|}
\hline & Population/disease & $\begin{array}{l}\text { Treatment strategy/dose and } \\
\text { duration }\end{array}$ & $\begin{array}{l}\text { Effect on pMV } \\
\text { concentration }\end{array}$ & Reference & $\begin{array}{l}\text { Supplementary } \\
\text { information }\end{array}$ \\
\hline & & $\begin{array}{l}\text { loading dose was } 300 \mathrm{mg} \text {, } \\
\text { followed by } 75 \mathrm{mg} \text { daily) }\end{array}$ & & & \\
\hline & $\begin{array}{l}\text { Hyperlipidemic, diabetic } \\
\text { patients }\end{array}$ & Pitavastatin $2 \mathrm{mg} /$ day for 6 months & No effect & [93] & \\
\hline & $\begin{array}{l}\text { Hyperlipidemic, diabetic } \\
\text { patients }\end{array}$ & $\begin{array}{l}\text { Combined therapy with pitavastatin } \\
(2 \mathrm{mg} / \text { day }) \text { and EPA } \\
(1800 \mathrm{mg} / \text { day }) \text { for } 6 \text { months }\end{array}$ & $\downarrow$ & {$[93]$} & \\
\hline & $\begin{array}{l}\text { Diabetes type } 1 \text { with } \\
\text { dyslipidemia }\end{array}$ & $\begin{array}{l}\text { Atorvastatin ( } 80 \mathrm{mg} / \text { day) for } \\
2 \text { months }\end{array}$ & $\begin{array}{l}\downarrow \text { Exposition of } \\
\quad \text { surface } \\
\text { markers }\end{array}$ & [116] & $\begin{array}{l}\downarrow \text { Exposition of GPIIIa, } \\
\text { P-selectin on pMVs } \\
\text { PP }\end{array}$ \\
\hline & $\begin{array}{l}\text { Diabetic patients with or } \\
\text { without chronic kidney } \\
\text { disease }\end{array}$ & $\begin{array}{l}\text { Simvastatin } 40 \mathrm{mg} / \text { day for } \\
8-10 \text { weeks }\end{array}$ & $\begin{array}{l}\downarrow \text { Exposition of } \\
\text { surface } \\
\text { markers }\end{array}$ & {$[32]$} & $\begin{array}{l}\downarrow \text { P-selectin, CD40L } \\
\quad \text { exposition on pMVs } \\
\mathrm{PP}\end{array}$ \\
\hline & Type 2 diabetes & Pravastatin $40 \mathrm{mg} /$ day for 8 weeks & $\begin{array}{l}\downarrow \text { Exposition of } \\
\text { surface } \\
\text { markers } \\
\text { No effect on } \\
\text { pMV } \\
\text { concentration }\end{array}$ & [117] & $\begin{array}{l}\downarrow \text { Exposition of GPIIIa } \\
\text { receptor for fibrinogen on } \\
\text { pMVs }\end{array}$ \\
\hline \multirow[t]{2}{*}{ Fibrates } & $\begin{array}{l}\text { Patients with connective } \\
\text { tissue diseases and } \\
\text { secondary } \\
\text { hyperlipidemia caused } \\
\text { by long-term steroid ad- } \\
\text { ministration }\end{array}$ & 6-month treatment with bezafibrate & $\downarrow$ & {$[33]$} & \\
\hline & $\begin{array}{l}\text { Patients with diabetes } \\
\text { without obstructive } \\
\text { CAD }\end{array}$ & $400 \mathrm{mg} /$ day bezafibrate for 6 weeks & $\downarrow$ & {$[34]$} & PP \\
\hline \multirow[t]{3}{*}{$\begin{array}{l}\text { Intestinal } \\
\text { cholesterol } \\
\text { absorption } \\
\text { inhibitors }\end{array}$} & $\begin{array}{l}\text { Diabetic patients with or } \\
\text { without chronic kidney } \\
\text { disease }\end{array}$ & $\begin{array}{l}\text { Simvastatin }(40 \mathrm{mg} / \text { day }) \text { and } \\
\text { ezetimibe }(10 \mathrm{mg} / \text { day }) \text { for } \\
8-10 \text { weeks }\end{array}$ & No effect & {$[32]$} & $\begin{array}{l}\text { No further effect on pMV } \\
\text { formation compared to } \\
\text { simvastatin therapy alone } \\
\text { PP }\end{array}$ \\
\hline & Patients with stable $\mathrm{CAD}$ & $10 \mathrm{mg} /$ day ezetimibe for 1 week & No effect & {$[84]$} & \\
\hline & $\begin{array}{l}\text { Subjects with CAD risk } \\
\text { factors receiving } \\
\text { concomitant therapy } \\
\text { with simvastatin and } \\
\text { ezetimibe }\end{array}$ & $10 \mathrm{mg} /$ day ezetimibe for 4 weeks & No effect & {$[122]$} & PP \\
\hline \multirow[t]{4}{*}{ Omega-3 PUFA } & Healthy males and females & $\begin{array}{l}\text { Single dose of EPA-rich (providing } \\
1 \mathrm{~g} \text { EPA with an EPA/DHA ratio } \\
\text { of 5:1) or DHA-rich (providing } \\
1 \mathrm{~g} \text { DHA with an EPA/DHA ratio } \\
\text { of } 1: 5 \text { ) oil }\end{array}$ & No effect & [134] & $\begin{array}{l}\text { Newly released pMV have } \\
\text { reduced procoagulant } \\
\text { properties, no effect on } \\
\text { pMV number }\end{array}$ \\
\hline & $\begin{array}{l}\text { Hyperlipidemic patients } \\
\text { with type } 2 \text { diabetes }\end{array}$ & $\begin{array}{l}\text { EPA } 1800 \mathrm{mg} \text { daily for } 6 \text { months or } \\
\text { combined therapy with } \\
\text { pitavastatin ( } 2 \mathrm{mg} / \text { day }) \text { and EPA } \\
(1800 \mathrm{mg} / \text { day }) \text { for } 6 \text { months }\end{array}$ & $\downarrow$ & {$[93]$} & $\begin{array}{l}\text { Higher reduction than that } \\
\text { observed with EPA alone }\end{array}$ \\
\hline & $\begin{array}{l}\text { Patients after myocardial } \\
\text { infarction }\end{array}$ & $\begin{array}{l}\text { Long-lasting (over } 12 \text { weeks) } \\
\text { administration of EPA and DHA }\end{array}$ & $\downarrow$ & {$[36]$} & $\begin{array}{l}\text { Normalization of both } \\
\text { elevated concentration as } \\
\text { well as TF-dependent } \\
\text { procoagulant activity of } \\
\text { pMV } \\
\text { SP }\end{array}$ \\
\hline & $\begin{array}{l}\text { Hyperlipidemic patients } \\
\text { with type } 2 \text { diabetes }\end{array}$ & EPA (1800 mg/day) for 4 weeks & $\downarrow$ & {$[37]$} & \\
\hline \multirow[t]{2}{*}{$\begin{array}{l}\text { Hypoglycemic } \\
\text { therapy }\end{array}$} & $\begin{array}{l}\text { Diabetes type } 2 \text { with or } \\
\text { without hemodialysis } \\
\text { treatment }\end{array}$ & $\begin{array}{l}\text { Teneligliptin } 20 \mathrm{mg} / \text { day for } \\
6 \text { months }\end{array}$ & $\downarrow$ & [39] & \\
\hline & $\begin{array}{l}\text { Patients with type } 2 \\
\text { diabetes }\end{array}$ & Miglitol $150 \mathrm{mg}$ /day for 4 months & $\downarrow$ & {$[38]$} & \\
\hline
\end{tabular}


Table 2 (continued)

\begin{tabular}{|c|c|c|c|c|c|}
\hline & Population/disease & $\begin{array}{l}\text { Treatment strategy/dose and } \\
\text { duration }\end{array}$ & $\begin{array}{l}\text { Effect on pMV } \\
\text { concentration }\end{array}$ & Reference & $\begin{array}{l}\text { Supplementary } \\
\text { information }\end{array}$ \\
\hline & Diabetic patients & Acarbose $300 \mathrm{mg} /$ day for 3 months & $\downarrow$ & {$[40]$} & \\
\hline & Diabetic patients & Miglitol $30 \mathrm{mg} /$ day for 3 months & $\downarrow$ & {$[127]$} & \\
\hline \multirow[t]{9}{*}{$\begin{array}{l}\text { Antihypertensive } \\
\text { therapy }\end{array}$} & Patients with recurrent TIA & $\begin{array}{l}\text { Nifedipine }(30-60 \mathrm{mg}) \text { for } \\
1-6 \text { weeks }\end{array}$ & $\downarrow$ & {$[7]$} & $\mathrm{SP}$ \\
\hline & Patients after ACS & $\begin{array}{l}\text { Different calcium channel } \\
\text { antagonists for } 6 \text { months }\end{array}$ & $\downarrow$ & {$[41]$} & $\begin{array}{l}\downarrow \text { pMV number (compared to } \\
\text { those not receiving such } \\
\text { treatment) SP }\end{array}$ \\
\hline & $\begin{array}{l}\text { Hypertensive, diabetic } \\
\text { patients }\end{array}$ & Losartan $50 \mathrm{mg} /$ day for 24 weeks & $\downarrow$ & [114] & \\
\hline & $\begin{array}{l}\text { Hypertensive, } \\
\text { hyperlipidemic patients } \\
\text { with or without diabetes }\end{array}$ & $\begin{array}{l}\text { Losartan }(50 \mathrm{mg} / \text { day }) \text { and } \\
\text { simvastatin }(10 \mathrm{mg} / \text { day }) \text { for } \\
24 \text { weeks }\end{array}$ & $\downarrow$ & [114] & $\begin{array}{l}\downarrow \text { pMV percentage (greater } \\
\text { among those with than } \\
\text { without type } 2 \text { diabetes) }\end{array}$ \\
\hline & $\begin{array}{l}\text { Hypertensive patients with } \\
\text { diabetes type } 2\end{array}$ & Nifedipine $50 \mathrm{mg} /$ day for 12 months & $\downarrow$ & [42] & \\
\hline & $\begin{array}{l}\text { Hypertensive patients with } \\
\text { diabetes type } 2\end{array}$ & $\begin{array}{l}\text { Long-acting nifedipine formulation } \\
20 \mathrm{mg} / \text { day for } 6 \text { months }\end{array}$ & $\downarrow$ & {$[43]$} & \\
\hline & $\begin{array}{l}\text { Hypertensive patients with } \\
\text { or without diabetes }\end{array}$ & Efonidipine $40 \mathrm{mg} /$ day for 8 weeks & $\downarrow$ & {$[44]$} & \\
\hline & Hypertensive patients & Eprosartan $600 \mathrm{mg} /$ day & $\downarrow$ & {$[132]$} & \\
\hline & $\begin{array}{l}\text { Animal model of } \\
\text { hypertension }\end{array}$ & Spironolactone & $\downarrow$ & [133] & \\
\hline \multirow[t]{4}{*}{$\begin{array}{l}\text { Non- } \\
\text { pharmacological } \\
\text { interventions }\end{array}$} & Healthy men & $\begin{array}{l}\text { Two consecutive high-fat meals } \\
\text { (900 kcal) at time point } t=0 \text { and } \\
4 \mathrm{~h} \text { (breakfast and lunch); each } \\
\text { meal consisted of } 50 \mathrm{~g} \text { of fat, of } \\
\text { which } 60 \% \text { was saturated, } 55 \mathrm{~g} \text { of } \\
\text { carbohydrates, and } 30 \mathrm{~g} \text { of protein } \\
\text { within } 15 \mathrm{~min}\end{array}$ & $\uparrow$ & [141] & \\
\hline & Animal model (rat) & $\begin{array}{l}\text { High-fat diet (providing } 60 \% \text { of } \\
\text { energy as fat) for } 20 \text { weeks }\end{array}$ & $\uparrow$ & {$[142]$} & $\begin{array}{l}\uparrow \text { Total MV number } \\
\text { significant } \uparrow \text { pMV number }\end{array}$ \\
\hline & Obese $\left(\mathrm{BMI}>25 \mathrm{~kg} / \mathrm{m}^{2}\right)$ & $\begin{array}{l}\text { Reducing calorie intake with as well } \\
\text { as without aerobic physical } \\
\text { exercise [mean daily caloric } \\
\text { intake approximately } \\
1200 \mathrm{kcal} / \text { day }+, 1680 \mathrm{kcal} / \text { day } \\
\text { with or without aerobic } \\
\text { exercise } 3 \text { days per week ( } 60 \text { min } \\
\text { per session)] }\end{array}$ & $\downarrow$ & {$[14]$} & $\begin{array}{l}\text { A mean weight loss of } 8 \mathrm{~kg} \text { in } \\
\text { moderately obese subjects } \\
\left(\text { mean } \mathrm{BMI}=27.4 \mathrm{~kg} / \mathrm{m}^{2}\right)\end{array}$ \\
\hline & $\begin{array}{l}\text { Obese women } \\
\qquad\left(\mathrm{BMI}>30 \mathrm{~kg} / \mathrm{m}^{2}\right)\end{array}$ & $\begin{array}{l}\text { Short-term very-low-calorie diet } \\
(600 \mathrm{kcal} / \text { day for } 1 \text { month and } \\
\text { then } 1200 \mathrm{kcal} / \text { day during the } \\
\text { second month) }\end{array}$ & $\downarrow$ & {$[45]$} & $\begin{array}{l}\downarrow \text { Procoagulant pMV } \\
\text { percentage }\end{array}$ \\
\hline \multirow[t]{4}{*}{ Omega-3 PUFA } & Healthy males and females & $\begin{array}{l}\text { Single dose of EPA-rich (providing } \\
1 \mathrm{~g} \text { EPA with an EPA/DHA ratio } \\
\text { of } 5: 1 \text { ) or DHA-rich (providing } \\
1 \mathrm{~g} \text { DHA with an EPA/DHA ratio } \\
\text { of } 1: 5 \text { ) oil }\end{array}$ & No effect & {$[134]$} & $\begin{array}{l}\text { Newly released pMVs have } \\
\text { reduced procoagulant } \\
\text { properties, no effect on } \\
\text { pMV number }\end{array}$ \\
\hline & $\begin{array}{l}\text { Hyperlipidemic patients } \\
\text { with type } 2 \text { diabetes }\end{array}$ & $\begin{array}{l}\text { EPA } 1800 \mathrm{mg} \text { daily for } 6 \text { months or } \\
\text { combined therapy with } \\
\text { pitavastatin }(2 \mathrm{mg} / \text { day }) \text { and EPA } \\
(1800 \mathrm{mg} / \text { day }) \text { for } 6 \text { months }\end{array}$ & $\downarrow$ & [93] & $\begin{array}{l}\text { Higher reduction than that } \\
\text { observed with EPA alone }\end{array}$ \\
\hline & $\begin{array}{l}\text { Patients after myocardial } \\
\text { infarction }\end{array}$ & $\begin{array}{l}\text { Long-lasting (over } 12 \text { weeks) } \\
\text { administration of EPA and DHA }\end{array}$ & $\downarrow$ & {$[36]$} & $\begin{array}{l}\text { Normalization of both } \\
\text { elevated concentration as } \\
\text { well as TF-dependent } \\
\text { procoagulant activity of } \\
\text { pMV } \\
\text { SP }\end{array}$ \\
\hline & $\begin{array}{l}\text { Hyperlipidemic patients } \\
\text { with type } 2 \text { diabetes }\end{array}$ & EPA (1800 mg/day) for 4 weeks & $\downarrow$ & {$[37]$} & \\
\hline
\end{tabular}


$A C S$ acute coronary syndrome, $A D P$ adenosine diphosphate, $A F$ atrial fibrillation, $A S A$ acetylsalicylic acid, $B M I$ body mass index, $C A D$ coronary artery disease, $C O X$ cyclooxygenase, $C T$ computed tomography, $D A P T$ dual antiplatelet therapy, $D H A$ docosahexaenoic acid, $D V T$ deep vein thrombosis, $E P A$ eicosapentaenoic acid, GP glicoprotein, INR international normalized ratio, ITP idiopathic thrombocytopenic purpura, $I V$ intravenous, $L M W H$ lowmolecular-weight heparin, $M V$ microvesicles, NSTEMI non-ST elevation myocardial infarction, PAOD peripheral arterial occlusive disease, $P C I$ percutaneous coronary intervention, $P D E$ phosphodiestherase, $p M V$ platelet-derived microvesicles, $P P$ primary vascular disease prevention, $P U F A s$ polyunsaturated fatty acids, SP secondary vascular disease prevention, STEMI ST elevation myocardial infarction, TF tissue factor, TIA transient ischemic attack

[143]. It was also demonstrated that cocoa consumption suppressed ADP-induced or epinephrine-induced platelet activation and hence pMV formation. The proportion of MV detected by flow cytometry was reduced up to $6 \mathrm{~h}$ after consumption of the beverage cocoa, unlike the formation of MV after consumption of a caffeine-containing beverage, which was higher than baseline [143].

Red wine polyphenols have beneficial properties for preventing cardiovascular disorders by their influence on NO balance and prevention of oxidative stress. In an experimental rat model of aldosterone-mediated hypertension, red wine polyphenols also significantly reduced pMV formation [133]. Interestingly, preconsumption of red wine prevented most of the acute effects of cigarette smoking, including reduced concentration of IL-6 protein and pMV increase [144].

Cigarette smoking is considered one of the major risk factors for atherothrombotic disease, including ischemic heart disease and stroke, and increases the risk of cardiovascular mortality. Active smoking even of one cigarette caused an immediate and significant increase in the number of circulating pMV, with a significant increase in pMV exposing CD62P and CD154 on their surface in healthy volunteers, most likely due to cell activation in response to cigarette smoke [145].

\section{Summary}

Platelet-derived microvesicles exhibit a multitude of properties and participate in several pathological conditions. Researchers have started to pay attention to MV as novel biomarkers in vascular diseases, especially in cardiovascular risk stratification. The influence of pharmacological agents on circulating pMV may become a new therapeutic challenge in the treatment of many vascular diseases. Not only modulation of pMV release but also exposure of their surface markers could have significant therapeutic application to monitor the efficacy of antiplatelet therapy. This modulation has resulted in a series of studies dedicated to the inhibition of MV release, especially those of platelet origin (Table 2). The different methodology of isolation of pMV, as well as the use of different quantification methods, the unequal doses of studied drugs, small study groups, or different treatment duration, makes the comparison between available studies difficult. Moreover, the lack of standardized methodology resulted for a long time in overestimation of the fraction of circulating pMV, and exposure of PS or
TF on pMV is often an artifact caused by non-specific antibody binding in flow cytometric analysis.

In conclusion, inhibitors of the ADP receptor and statins are the most promising drugs that limit the unfavorable impact of pMV in both primary prevention and secondary prevention of vascular disease. Promising agents also include the GP IIb/IIIa antagonists, but their use is limited to acute cardiovascular disease. Treatment with ASA, an irreversible COX inhibitor, despite convincing theoretical justification, does not influence pMV release, and its role as an anti-pMV agent seems to be limited. Although there is considerable research into the effects of vascular disease treatment on pMV, their use as both potential markers in vascular diseases and monitoring of treatment is still questionable due to the lack of comparability of results and the lack of standardized methods for microparticle determination. Further studies are required to understand how pMVs respond to treatment and to determine the potential mechanisms of drug action, effective dosages, and drug interactions in the context of prevention and treatment of vascular diseases.

Funding Information This study was funded by the governmental research grant National Science Centre 2014/15/B/NZ4/00736.

\section{Compliance with Ethical Standards}

Conflict of Interest The authors declare that they have no conflict of interest.

Human and Animal Rights and Informed Consent This article does not contain any studies with human participants or animals performed by any of the authors.

Open Access This article is distributed under the terms of the Creative Commons Attribution 4.0 International License (http:// creativecommons.org/licenses/by/4.0/), which permits unrestricted use, distribution, and reproduction in any medium, provided you give appropriate credit to the original author(s) and the source, provide a link to the Creative Commons license, and indicate if changes were made.

\section{References}

1. Wolf $\mathrm{P}$. The nature and significance of platelet products in human plasma. Br J Haematol. 1967;13:269-88. 
2. Berckmans RJ, Nieuwland R, Boing AN, Romijn FP, Hack CE, Sturk A. Cell-derived microparticles circulate in healthy humans and support low grade thrombin generation. Thromb Haemost. 2001;85:639-46.

3. Aatonen M, Grönholm M, Siljander PR. Platelet-derived microvesicles: multitalented participants in intercellular communication. Semin Thromb Hemost. 2012;38:102-13.

4. Horstman LL, Ahn YS. Platelet microparticles: a wide-angle perspective. Crit Rev Oncol Hematol. 1999;30:111-42.

5. Lukasik M, Rozalski M, Luzak B, et al. Enhanced platelet-derived microparticle formation is associated with carotid atherosclerosis in convalescent stroke patients. Platelets. 2012;24:63-70.

6. Cherian P, Hankey GJ, Eikelboom JW, et al. Endothelial and platelet activation in acute ischemic stroke and its etiological subtypes. Stroke. 2003;34:2132-7.

7. Lee YJ, Jy W, Horstman LL, et al. Elevated platelet microparticles in transient ischemic attacks, lacunar infarcts, and multiinfarct dementias. Thromb Res. 1993;72:295-304.

8. Shirafuji T, Hamaguchi H, Kanda F. Measurement of plateletderived microparticle levels in the chronic phase of cerebral infarction using an enzyme-linked immunosorbent assay. Kobe $\mathrm{J}$ Med Sci. 2008;54:55-61.

9. Bulut D, Becker V, Mügge A. Acetylsalicylate reduces endothelial and platelet-derived microparticles in patients with coronary artery disease. Can J Physiol Pharmacol. 2011;89:239-44.

10. George M, Ganesh MR, Sridhar A, et al. Evaluation of endothelial and platelet derived microparticles in patients with acute coronary syndrome. J Clin Diagn Res. 2015;9:OC09-13.

11. Michelsen AE, Brodin E, Brosstad F, Hansen JB. Increased level of platelet microparticles in survivors of myocardial infarction. Scand J Clin Lab Invest. 2008;68:386-92.

12. Preston RA, Jy W, Jiminez JJ, et al. Effects of severe hypertension on endothelial and platelet microparticles. Hypertension. 2003;41:211-7.

13. Sabatier F, Darmon P, Hugel B, et al. Type 1 and type 2 diabetic patients display different patterns of cellular microparticles. Diabetes. 2002;51:2840-5.

14. Murakami T, Horigome H, Tanaka K, et al. Impact of weight reduction on production of platelet-derived microparticles and fibrinolytic parameters in obesity. Thromb Res. 2007;119:45-53.

15. Stepanian A, Bourguignat L, Hennou S, et al. Microparticle increase in severe obesity: not related to metabolic syndrome and unchanged after massive weight loss. Obesity. 2013;21:2236-43.

16. Kim HK, Song KS, Park YS, et al. Elevated levels of circulating platelet microparticles, VEGF, IL-6 and RANTES in patients with gastric cancer: possible role of a metastasis predictor. Eur J Cancer. 2003;39:184-91.

17. Hron G, Kollars M, Weber H, et al. Tissue factor-positive microparticles: cellular origin and association with coagulation activation in patients with colorectal cancer. Thromb Haemost. 2007;97:119-23.

18. Zhang Y, Liu X, Liu L. Contact- and agonist-regulated microvesiculation of human platelets. Thromb Haemost. 2013;110:331-9.

19. França CN, Pinheiro LF, Izar MC, et al. Endothelial progenitor cell mobilization and platelet microparticle release are influenced by clopidogrel plasma levels in stable coronary artery disease. Circ J. 2012;76:729-36.

20. Kafian S, Mobarrez F, Wallen H, Samad B. Association between platelet reactivity and circulating platelet-derived microvesicles in patients with acute coronary syndrome. Platelets. 2015;26:467-73.

21. Nomura S, Shouzu A, Omoto S, Nishikawa M, Fukuhara S. Significance of chemokines and activated platelets in patients with diabetes. Clin Exp Immunol. 2000;121:437-43.

22. Nomura S, Shouzu A, Omoto S, et al. Effect of cilostazol on soluble adhesion molecules and platelet-derived microparticles in patients with diabetes. Thromb Haemost. 1998;80:388-92.
23. Omoto S, Nomura S, Shouzu A, et al. Significance of plateletderived microparticles and activated platelets in diabetic nephropathy. Nephron. 1999;81:271-7.

24. Chen Y, Xiao Y, Lin Z, et al. The role of circulating platelets microparticles and platelet parameters in acute ischemic stroke patients. J Stroke Cerebrovasc Dis. 2015;24:2313-20.

25. Goto S, Tamura N, Li M, et al. Different effects of various anti-GPIIbIIIIa agents on shear-induced platelet activation and expression of procoagulant activity. J Thromb Haemost. 2003;1:2022-30.

26. Böing A, Valkonen S, Sturk A, Hajji N, Chi Hau, Nieuwland R. Platelet-derived extracellular vesicles exposing fibrinogen may be a potential marker for ongoing thrombus formation. The Fifth International Meeting of ISEV, ISEV2016 Rotterdam, The Netherlands, 4-7 May, 2016 Abstracts.

27. Morel O, Hugel B, Jesel L, et al. Circulating procoagulant microparticles and soluble GPV in myocardial infarction treated by primary percutaneous transluminal coronary angioplasty. A possible role for GPIIb-IIIla antagonists. J Thromb Haemost. 2004;2:1118-26.

28. Dalby M, Montalescot G, Bal dit Sollier C, et al. Eptifibatide provides additional platelet inhibition in non-ST-elevation myocardial infarction patients already treated with aspirin and clopidogrel. Results of the platelet activity extinction in non-Qwave myocardial infarction with aspirin, clopidogrel, and eptifibatide (PEACE) study. J Am Coll Cardiol. 2004;43:162-8.

29. Šuštar V, Janša R, Frank M, et al. Suppression of membrane microvesiculation - a possible anticoagulant and anti-tumor progression effect of heparin. Bllod Cells Mol Dis. 2009;42:223-7.

30. Pawelczyk M, Chmielewski H, Kaczorowska B, Przybyła M, Baj $Z$. The influence of statin therapy on platelet activity markers in hyperlipidemic patients after ischemic stroke. Arch Med Sci. 2015;11:115-21.

31. Pinheiro LF, Franca CN, Izar MC, et al. Pharmacokinetic interactions between clopidogrel and rosuvastatin: effects on vascular protection in subjects with coronary heart disease. Int J Cardiol. 2012;158:125-9.

32. Almquist T, Mobar F, Jacobson SH, Wallén H, Hjemdahl P. Effects of lipid-lowering treatment on circulating microparticles in patients with diabetes mellitus and chronic kidney disease. Nephrol Dial Transplant. 2016;31:944-52.

33. Kagawa H, Nomura S, Nagahama M, Ozaki Y, Fukuhara S. Effect of bezafibrate on soluble adhesion molecules and platelet activation markers in patients with connective tissue diseases and secondary hyperlipidemia. Clin Appl Thromb Hemost. 2001;7:153-7.

34. Koga H, Sugiyama S, Kugiyama K, et al. Elevated levels of remnant lipoproteins are associated with plasma platelet microparticles in patients with type-2 diabetes mellitus without obstructive coronary artery disease. Eur Heart J. 2006;27:817-23.

35. Nomura S, Inami N, Shouzu A, et al. The effects of pitavastatin, eicosapentaenoic acid and combined therapy on platelet-derived microparticles and adiponectin in hyperlipidemic, diabetic patients. Platelets. 2009;20:16-22.

36. Del Turco S, Basta G, Lazzerini G, et al. Effect of the administration of n-3 polyunsaturated fatty acids on circulating levels of microparticles in patients with a previous myocardial infarction. Haematologica. 2008;93:892-9.

37. Nomura S, Kanazawa S, Fukuhara S. Effects of eicosapentaenoic acid on platelet activation markers and cell adhesion molecules in hyperlipidemic patients with type 2 diabetes mellitus. J Diabetes Complicat. 2003;17:153-9.

38. Nomura S, Omoto S, Yokoi T, et al. Effects of miglitol in plateletderived microparticle, adiponectin, and selectin level in patients with type 2 diabetes mellitus. Int J Gen Med. 2011;4:539-45.

39. Okuda Y, Omoto S, Taniura T, Shouzu A, Nomura S. Effects of teneligliptin on PDMPs and PAI-1 in patients with diabetes on hemodialysis. Int J Gen Med. 2016;9:65-71. 
40. Shimazu T, Inami N, Satoh D, et al. Effect of acarbose on plateletderived microparticles, soluble selectins, and adiponectin in diabetic patients. J Thromb Thrombolysis. 2009;28:429-35.

41. Skeppholm M, Mobarrez F, Malmqvist K, Wallén H. Plateletderived microparticles during and after acute coronary syndrome. Thromb Haemost. 2012;107:1122-9.

42. Nomura S, Shouzu A, Omoto S, Nishikawa M, Iwasaka T. Longterm treatment with nifedipine modulates procoagulant marker and $\mathrm{C}-\mathrm{C}$ chemokine in hypertensive patients with type 2 diabetes mellitus. Thromb Res. 2005;115:277-85.

43. Nomura S, Inami N, Kimura $\mathrm{Y}$, et al. Effect of nifedipine on adiponectin in hypertensive patients with type 2 diabetes mellitus. J Hum Hypertens. 2007;21:38-44.

44. Nomura S, Kanazawa S, Fukuhara S. Effects of efonidipine on platelet and monocyte activation markers in hypertensive patients with and without type 2 diabetes mellitus. J Hum Hypertens. 2002;16:539-47.

45. Morel O, Luca F, Grunebaum L, et al. Short-term very low-calorie diet in obese females improves the haemostatic balance through the reduction of leptin levels, PAI-1 concentrations and a diminished release of platelet and leukocyte-derived microparticles. Int J Obes. 2011;35:1479-86.

46. Miyazaki Y, Nomura S, Miyake T, et al. High shear stress can initiate both platelet aggregation and shedding of procoagulant containing microparticles. Blood. 1996;88:3456-64.

47. Holme PA, Orvim U, Hamers MJ, et al. Shear-induced platelet activation and platelet microparticle formation at blood flow conditions as in arteries with a severe stenosis. Arterioscler Thromb Vasc Biol. 1997; 17:646-53.

48. Bode AP, Knupp CL. Effect of cold storage on platelet glycoprotein Ib and vesiculation. Transfusion. 1994;34:690-6.

49. Gemmel CH, Sefton MV, Yeo E. Platelet-derived microparticle formation involves glycoprotein IIb-IIIa. Inhibition by RGDS and a Glanzmann's thrombasthenia defect. J Biol Chem. 1993;268:14586-9.

50. Van Wijk MJ, Van Bavel E, Sturk A, Nieuwland R. Microparticles in cardiovascular diseases. Cardiovasc Res. 2003;59:277-87.

51. Yano Y, Kambayashi J, Shiba E, et al. The role of protein phosphorylation and cytoskeletal reorganization in microparticle formation from the platelet plasma membrane. Biochem J. 1994;299: 303-8.

52. Distler JH, Huber LC, Hueber AJ, et al. The release of microparticles by apoptotic cells and their effects on macrophages. Apoptosis. 2005;10:731-41.

53. Cauwenberghs S, Feijge MA, Harper AG, Sage SO, Curvers J, Heemskerk JW. Shedding of procoagulant microparticles from unstimulated platelets by integrin-mediated destabilization of actin cytoskeleton. FEBS Lett. 2006;580:5313-20.

54. George JN, Pickett EB, Saucerman S, et al. Platelet surface glycoproteins. Studies on resting and activated platelets and platelet membrane microparticles in normal subjects, and observations in patients during adult respiratory distress syndrome and cardiac surgery. J Clin Invest. 1986;78:340-8.

55. Sprague DL, Elzey BD, Crist SA, Waldschmidt TJ, Jensen RJ, Ratliff TL. Platelet-mediated modulation of adaptive immunity: unique delivery of CD154 signal by platelet-derived membrane vesicles. Blood. 2008;111:5028-36.

56. Sims PJ, Faioni EM, Wiedmer T, Shattil SJ. Complement proteins C5b-9 cause release of membrane vesicles from the platelet surface that are enriched in the membrane receptor for coagulation factor Va and express prothrombinase activity. J Biol Chem. 1988;263:18205-12.

57. Milioli M, Ibanez-Vea M, Sidoli S, Palmisano G, Careri M, Larsen MR. Quantitative proteomics analysis of platelet-derived microparticles reveals distinct protein signatures when stimulated by different physiological agonists. J Proteome. 2015;121:56-66.
58. Boilard E, Duchez AC, Brisson A. The diversity of platelet microparticles. Curr Opin Hematol. 2015;22:437-44.

59. Flaumenhaft R, Dilks JR, Richardson J, et al. Megakaryocytederived microparticles: direct visualization and distinction from platelet-derived microparticles. Blood. 2009;113:1112-21.

60. Iwamoto S, Kawasaki T, Kambayashi J, Ariyoshi H, Monden M. Platelet microparticles: a carrier of platelet-activating factor? Biochem Biophys Res Commun. 1996;218:940-4.

61. Wartiovaara U, Salven P, Mikkola H, et al. Peripheral blood platelets express VEGF-C and VEGF which are released during platelet activation. Thromb Haemost. 1998;80:171-5.

62. Nomura S, Komiyama Y, Miyake T, et al. Amyloid-protein precursor-rich platelet microparticles in thrombotic disease. Thromb Haemost. 1994;72:519-22.

63. Tans G, Rosing J, Thomassen MC, Heeb MJ, Zwaal RF, Griffin $\mathrm{JH}$. Comparison of anticoagulant and procoagulant activities of stimulated platelets and platelet-derived microparticles. Blood. 1991;77:2641-8.

64. Barry OP, Practico D, Lawson JA, FitzGerald GA. Transcellular activation of platelets and endothelial cells by bioactive lipids in platelet microparticles. J Clin Invest. 1997;99:2118-27.

65. Garcia B, Smalley DM, Cho H, Shabanowitz J, Ley K, Hunt DF. The platelet particle proteome. J Proteome Res. 2005;4:1516-21.

66. Sinauridze EI, Kireev DA, Popenko NY, et al. Platelet microparticle membranes have 50 - to 100 -fold higher specific procoagulant activity than activated platelets. Thromb Haemost. 2007;97:425-34.

67. Nomura S, Ozaki Y, Ikeda Y. Function and role of microparticles in various clinical settings. Thromb Res. 2008;123:8-23.

68. Gilbert GE, Sims PJ, Wiedmer T, Furie B, Furie BC, Shattil SJ. Platelet derived microparticles express high affinity receptors for factor VIII. J Biol Chem. 1991;266:17261-8.

69. Hoffnan M, Monroe DM, Roberts HR. Coagulation factor IXa binding to activated platelets and platelet derived microparticles: a flow cytometric study. Thromb Haemost. 1992;68:74-8.

70. Chou J, Mackman N, Merrill-Skoloff G, Pedersen B, Furie BC, Furie B. Hematopoietic cell-derived microparticle tissue factor contributes to fibrin formation during thrombus propagation. Blood. 2004;104:3190-7.

71. Pfister SL. Role of platelet microparticles in the production of thromboxane by rabbit pulmonary artery. Hypertension. 2004;43:428-33.

72. Barry OP, Practico D, Savani RC, FitzGerald GA. Modulation of monocyte-endothelial cell interactions by platelet microparticles. J Clin Invest. 1998;102:136- 44.

73. Mause SF, von Hundelshausen P, Zernecke A, Koenen RR, Weber C. Platelet microparticles: a transcellular delivery system for RANTES promoting monocyte recruitment on endothelium. Arterioscler Thromb Vasc Biol. 2005;25:1512-8.

74. Forlow SB, McEver R, Nollert MU. Leukocyte-leukocyte interactions mediated by platelet microparticles under flow. Blood. 2000;95:1317-23.

75. Janowska-Wieczorek A, Wysoczynski M, Kijowski J, MarquezCurtis L, Machalinski B, Ratajczak J. Microvesicles derived from activated platelets induce metastasis and angiogenesis in lung cancer. Int J Cancer. 2005;113:752-60.

76. Laffont B, Corduan A, Plé H, et al. Activated platelets can deliver mRNA regulatory Ago2 $\bullet$ microRNA complexes to endothelial cells via microparticles. Blood. 2013;122:253-61.

77. Yuana Y, Bertina RM, Osanto S. Pre-analytical and analytical issues in the analysis of blood microparticles. Thromb Haemost. 2011;105:396-408.

78. Lacroix R, Robert S, Poncelet P, Kasthuri RS, Key NS, DignatGeorge F. Standardization of platelet-derived microparticle enumeration by flow cytometry using calibrated beads: results of ISTH SSC collaborative workshop. J Thromb Haemost. 2010;8:2571-2. 
79. Vane JR, Bakhle YS, Botting RM. Cyclooxygenase 1 and 2. Annu Rev Pharmacol Toxicol. 1998;38:97-120.

80. Barry OP, Kazanietz MG, Practico D, FitzGerald GA. Arachidonic acid in platelet microparticles up-regulates cyclooxygenase-2-dependent prostaglandin formation via a protein kinase c/mitogen-activated protein kinase-dependent pathway. J Biol Chem. 1999;274:7545-56.

81. Choudhury A, Chung I, Blann AD, Lip GY. Elevated platelet microparticle levels in nonvalvular atrial fibrillation: relationship to p-selectin and antithrombotic therapy. Chest. 2007;131:809-15.

82. Duarte RC, Gonçalves LH, Campos FM, et al. Effect of acetylsalicylic acid on platelet activation and oxidative profile in a set of Brazilian patients with type 2 diabetes mellitus. Blood Coagul Fibrinolysis. 2015;26:123-30.

83. Chiva-Blanch G, Suades R, Padro T, et al. Microparticle shedding by erythrocytes, monocytes and vascular smooth muscular cells is reduced by aspirin in diabetic patients. Rev Esp Cardiol. 2016;69: 672-80.

84. Camargo LM, Franca CN, Izar MC, et al. Effects of simvastatin/ ezetimibe on microparticles, endothelial progenitor cells and platelet aggregation in subjects with coronary heart disease under antiplatelet therapy. Braz J Med Biol Res. 2014;47:432-7.

85. Combes V, Joly P, Ambrosi P, et al. Platelet vesiculation in angina patients treated with coronary angioplasty. Thromb Haemost. 2000;83:518.

86. Mobarrez F, He S, Bröijersen A, et al. Atorvastatin reduces thrombin generation and expression of tissue factor, P-selectin and GPIIIa on platelet-derived microparticles in patients with peripheral arterial occlusive disease. Thromb Haemost. 2011;106:344-52.

87. Lubsczyk B, Kollars M, Hron G, et al. Low dose acetylsalicylic acid and shedding of microparticles in vivo in humans. Eur J Clin Investig. 2010;40:477-82.

88. Kalantzi KI, Dimitriou AA, Goudevenos JA, Tselepsis AD. The platelet hyporesponsiveness to clopidogrel in acute coronary syndrome patients treated with $75 \mathrm{mg}$ /day clopidogrel may be overcome within 1 month of treatment. Platelets. 2012;23:121-31.

89. Judge HM, Buckland RJ, Sugidachi A, Jakubowski JA, Storey RF. Relationship between degree of P2Y12 receptor blockade and inhibition of P2Y12-mediated platelet function. Thromb Haemost. 2010;103:1210-7.

90. Storey RF, Sanderson HM, White AE, May JA, Cameron KE, Heptinstall S. The central role of the P2T receptor in amplification of human platelet activation, aggregation, secretion and procoagulant activity. Br J Haematol. 2000;110:925-34.

91. Kahner BN, Dorsam RT, Kunapuli SP. Role of P2Y receptor subtypes in platelet-derived microparticle generation. Front Biosci. 2008;13:433-9.

92. Jung WK, Lee DY, Park C, et al. Cilostazol is anti-inflammatory in BV2 microglial cells by inactivating nuclear factor-kappaB and inhibiting mitogen-activated protein kinases. Br J Pharmacol. 2010;159:1274-85.

93. Nomura S, Inami N, Iwasaka T, Liu Y. Platelet activation markers, microparticles and soluble adhesion molecules are elevated in patients with arteriosclerosis obliterans: therapeutic effects by cilostazol and potentiation by dipyridamole. Platelets. 2004;15: 167-72.

94. Li H, Cone J, Fong M, Kambayashi J, Yoshitake M, Liu Y. Antiplatelet and antithrombotic activity of cilostazol is potentiated by dipyridamole in rabbits and dissociated from bleeding time prolongation. Cardiovasc Drugs Ther. 2005;1:41-8.

95. Ichijo M, Ishibashi S, Ohkubo T, et al. Elevated platelet microparticle levels after acute ischemic stroke with concurrent idiopathic thrombocytopenic purpura. J Stroke Cerebrovasc Dis. 2014;23:587-9.

96. Wagner CL, Mascelli MA, Neblock DS. Analysis of GP IIb/IIIa receptor number by quantification of 7E3 binding to human platelets. Blood. 1996;88:907-14.
97. Calvete JJ. Clues for understanding the structure and function of a prototypic human integrin: the platelet glycoprotein IIb/IIIa complex. Thromb Haemost. 1994;72:1-15.

98. Jeske WP, Walenga JM, Bakhos M. Effect of glycoprotein IIb/IIIa antagonists on the HIT serum induced activation of platelets. Thromb Res. 1997;88:271-81.

99. Matzdorf AC, Kuhnel G, Kemkes-Matthes B, Pralle H, Voss R, Farred J. Effect of glycoprotein IIb/IIIa inhibitors on CD62p expression, platelet aggregates, and microparticles in vitro. J Lab Clin Med. 2000;135:247-55.

100. Craft JA, Marsh NA. Increased generation of platelet-derived microparticles following percutaneous transluminal coronary angioplasty. Blood Coagul Fibrinolysis. 2003;14:719-28.

101. Nagy B Jr, Szuk T, Debreceni IB, Kappelmayer J. Platelet-derived microparticle levels are significantly elevated in patients treated by elective stenting compared to subjects with diagnostic catheterization alone. Platelets. 2010;21:147-51.

102. Vargova K, Pállinger E, Horváth Z, et al. Drug-eluting stents promote late platelet-derived microvesicle release. Exp Clin Cardiol. 2014;20:3713-22.

103. Tamburrelli C, Crescente M, Izzi B, et al. Epoprostenol inhibits human platelet-leukocyte mixed conjugate and platelet microparticle formation in whole blood. Thromb Res. 2011;128:446-51.

104. Warkentin TE, Hayward CPM, Boshkov LK, et al. Sera from patients with heparin-induced thrombocytopenia generate platelet-derived microparticles with procoagulant activity: an explanation for the thrombotic complications of heparin-induced thrombocytopenia. Blood. 1994;84:3691-9.

105. Otero R, Elias T, Montes-Worboys A, et al. Effects of long-term anticoagulant therapy on levels of circulating microparticles in patients with deep venous thrombosis. Blood Coagul Fibrinolysis. 2011;22:628-9.

106. Amirkhosravi A, Mousa S, Amaya M, Francis J. Antimetastatic effect of tinzaparin, a low-molecular-weight heparin. J Thromb Haemost. 2003;1:1972-6.

107. Pepke W, Eisenreich A, Jaster M, et al. Bivalirudin inhibits periprocedural platelet function and tissue factor expression of human smooth muscle cells. Cardiovasc Ther. 2013;31:115-23.

108. Holme PA, Brosstad F, Solum NO. Platelet-derived microvesicles and activated platelet express factor Xa activity. Blood Coagul Fibrinol. 1995;6:302-10.

109. Hérault B, Perrin C, Jongbloet AM, et al. Effect of factor Xa inhibitors on the platelet-derived microparticles procoagulant activity in vitro and in vivo in rats. Thromb Haemost. 2000;84:668-74.

110. Steppich B, Dobler F, Brendel LC, et al. Effect of the FXa inhibitors Rivaroxaban and Apixaban on platelet activation in patients with atrial fibrillation. J Thromb Thrombolysis. 2017;43:490-7.

111. Suades R, Padró T, Alonso R, Mata P, Badimon L. Lipid-lowering therapy with statins reduces microparticle shedding from endothelium, platelets and inflammatory cells. Thromb Haemost. 2013;110:366-77.

112. Tramontano AF, O’Leary J, Black AD, Muniyappa R, Cutaia MV, El-Sherif N. Statin decreases endothelial microparticle release from human coronary artery endothelial cells: implication for the Rhokinase pathway. Biochem Biophys Res Commun. 2004;320:34-8.

113. Stach K, Nguyen XD, Lang S, et al. Simvastatin and atorvastatin attenuate VCAM-1 and uPAR expression on human endothelial cells and platelet surface expression of CD40 ligand. Cardiol J. 2012;19:20-8.

114. Nomura S, Shouzu A, Omoto S, Nishikawa M, Fukuhara S, Iwasaka T. Losartan and simvastatin inhibit platelet activation in hypertensive patients. J Thromb Thrombolysis. 2004;18:177-85.

115. Rezaie-Majd A, Maca T, Bucek RA, et al. Simvastatin reduces expression of cytokines interleukin- 6 , interleukin-8, and monocyte chemoattractant protein-1 in circulating monocytes from 
hypercholesterolemic patients. Arterioscler Thromb Vasc Biol. 2002;22:1194-9.

116. Tehrani S, Mobarrez F, Antovic A, et al. Atorvastatin has antithrombotic effects in patients with type 1 diabetes and dyslipidemia. Thromb Res. 2010;126:225-31.

117. Sommeijer DW, Joop K, Leyte A, Reitsma PH, ten Cate H. Pravastatin reduces fibrinogen receptor gpIIIa on platelet-derived microparticles in patients with type 2 diabetes. J Thromb Haemost. 2005;3:1168-71.

118. Ali FY, Armstrong PC, Dhanji AR, et al. Antiplatelet actions of statins and fibrates are mediated by PPARs. Arterioscler Thromb Vasc Biol. 2009;29:706-11.

119. Ali FY, Hall MG, Desvergne B, Warner TD, Mitchell JA. PPARbeta/delta agonists modulate platelet function via mechanism involving PPAR receptors and specific association/ repression of PKC alpha-brief report. Arterioscler Thromb Vasc Biol. 2009;29:1871-3.

120. Akbiyik F, Ray DM, Gettings KF, Blumberg N, Francis CW, Phipps RP. Human bone marrow megakaryocytes and platelets express PPARgamma, and PPARgamma agonists blunt platelet release of CD40 ligand and thromboxanes. Blood. 2004;104:1361-8.

121. Chang TY, Chang C. Ezetimibe blocks internalization of the NPC1L1/cholesterol complex. Cell Metab. 2008;7:469-71.

122. Lins LC, França CN, Fonseca FA, et al. Effects of ezetimibe on endothelial progenitor cells and microparticles in high-risk patients. Cell Biochem Biophys. 2014;70:687-96.

123. Lijnen P, Echevaría-Vázquez D, Petrov V. Influence of cholesterol-lowering on plasma membrane lipids and function. Methods Find Exp Clin Pharmacol. 1996;18:123-36.

124. Connolly KD, Willis GR, Datta Dev BN, et al. Lipoprotein apheresis reduces circulating microparticles in individuals with familial hypercholesterolemia. J Lipid Res. 2014;55:2064-72.

125. Nomura S, Suzuki M, Katsura K, et al. Platelet-derived microparticles may influence the development of atherosclerosis in diabetes mellitus. Atherosclerosis. 1995;116:235-40.

126. Goda M, Kadowaki T. Teneligliptin for the treatment of type 2 diabetes. Drugs Today. 2013;49:615-29.

127. Nomura S, Omoto S, Taniura T, Okuda Y, Shouzu. Combintion therapy of mitiglinide with alpha-glucosidase inhibitor and/or DPP-4I improves platelet-derived microparticle and adiponectin levels in patients with type 2 diabetes mellitus. J Endocrinol Diabetes. 2016;4:1081.

128. Moritoh Y, Takeuchi K, Hazama M. Chronic administration of voglibose, an alpha-glucosidase inhibitor, increases active glucagon-like peptide-1 levels by increasing its secretion and decreasing dipeptidyl peptidase-4 activity in ob/ob mice. J Pharmacol Exp Ther. 2009;329:669-76.

129. Esposito K, Ciotola M, Giugliano D. Pioglitazone reduces endothelial microparticles in the metabolic syndrome. Arterioslcer Thromb Vasc Biol. 2006;26:1926.

130. Tesse A, AL-Massarani G, Wangensteen R, Reitenbach S, Martınez MC. Andriantsitohaina rosiglitazone, a peroxisome proliferator-activated receptor-agonist, prevents microparticleinduced vascular hyporeactivity through the regulation of proinflammatory proteins. J Pharmacol Exp Ther. 2008;324:53-47.
131. Berkels R, Egink G, Marsen TA, Bartels H, Roesen R, Klaus W. Nifedipine increases endothelial nitric oxide bioavailability by antioxidative mechanisms. Hypertension. 2001;37:240-5.

132. Labiós M, Martínez M, Gabriel F, Guiral V, Ruiz Aja S, Aznar J. Effect of eprosartan on cytoplasmic free calcium mobilization, platelet activation, and microparticle formation in hypertension. Am J Hypertens. 2004;17:757-63.

133. López Andrés N, Tesse A, Regnault V, et al. Increased microparticle production and impaired microvascular endothelial function in aldosterone-salt-treated rats: protective effects of polyphenols. PLoS One. 2012;7:e39235.

134. Phang M, Lincz L, Seldon M, Garg ML. Acute supplementation with eicosapentaenoic acid reduces platelet microparticle activity in healthy subjects. J Nutr Biochem. 2012;23:1128-33.

135. Walz CP, Barry AR, Koshman SL. Omega-3 polyunsaturated fatty acid supplementation in the prevention of cardiovascular disease. Can Pharm J. 2016;149:166-73.

136. Campello E, Zabeo E, Radu CM, et al. Hypercoagulability in overweight and obese subjects who are asymptomatic for thrombotic events. Thromb Haemost. 2015;113:85-96.

137. Konstantinides S, Schafer K, Koschnick S, Loskutoff DJ. Leptindependent platelet aggregation and arterial thrombosis suggests a mechanism for atherothrombotic disease in obesity. J Clin Invest. 2001;108:1533-40.

138. Nakata M, Yada T, Soejima N, Maruyama I. Leptin promotes aggregation of human platelets via the long form of its receptor. Diabetes. 1999;48:426-9.

139. Lukasik M, Michalak S, Dworacki G, Kaczmarek M, Watala C, Kozubski W. Reactive leptin resistance and the profile of platelet activation in acute ischaemic stroke patients. Thromb Haemost. 2012;108:107-18.

140. Nomura S, Shouzu A, Omoto S, Nishikawa M, Iwasaka T, Fukuhara S. Activated platelet and oxidized LDL induce endothelial membrane vesiculation: clinical significance of endothelial cell-derived microparticles in patients with type 2 diabetes. Clin Appl Thromb Hemost. 2004;10:205-15.

141. Tushuizen ME, Nieuwland R, Scheffer PG, Sturk A, Heine RJ, Diamant M. Two consecutive high-fat meals affect endothelialdependent vasodilation, oxidative stress and cellular microparticles in healthy men. J Thromb Haemost. 2006;4:1003-10.

142. Heinrich LF, Andersen DK, Cleasby ME, Lawson C. Long-term high fat feeding of rats results in increased numbers of circulating microvesicles with pro-inflammatory effects on endothelial cells. Br J Nutr. 2015;113:1704-11.

143. Rein D, Paglieroni TG, Wun T, et al. Cocoa inhibits platelet activation and function. Am J Clin Nutr. 2000;72:30-5.

144. Schwartz V, Bachelier K, Schirmer SH, Werner C, Laufs U, Böhm M. Red wine prevents the acute negative vascular effects of smoking. Am J Med. 2017;130:95-100.

145. Mobarrez F, Antoniewicz L, Bosson JA, Kuhl J, Pisetsky DS, Lundbäck M. The effects of smoking on levels of endothelial progenitor cells and microparticles in the blood of healthy volunteers. PLoS One. 2014;9:e90314 